Review

\title{
Enzyme catalysis coupled with artificial membranes towards process intensification in biorefinery- a review
}

\author{
Rosalinda Mazzei ${ }^{\text {a, }}$, Abaynesh Yihdego Gebreyohannes ${ }^{\text {b, }}$, Emmaouil Papaioannou ${ }^{c}$, \\ Suzana P. Nunes ${ }^{b}$, Ivo F.J. Vankelecom ${ }^{\mathrm{d}}$, Lidietta Giorno ${ }^{\mathrm{a}}$ \\ a Institute on Membrane Technology, National Research Council, ITM-CNR, via P. Bucci, 17/C, I 87030 Rende (Cosenza), Italy \\ ${ }^{\mathrm{b}}$ King Abdullah University of Science and Technology (KAUST). Biological and Environmental Science and Engineering Division (BESE), Advanced Membranes and \\ Porous Materials Center (AMPM), 23955-6900 Thuwal, Saudi Arabia \\ ${ }^{c}$ Engineering Department, Lancaster University, Lancaster, LA1 4YW, United Kingdom \\ ${ }^{d}$ Membrane Technology Group, Division cMACS, Faculty of Bioscience Engineering. KU Leuven, Celestijnenlaan 200F, PO Box 2454, 3001 Leuven, Belgium
}

\section{H I G H L I G H T S}

- Enzymes combined with artificial membranes in biorefinery promote process intensification.

- The use of MBRs in biorefinery permit enzymes re-use and increased stability.

- The use of MBRs promote removal of enzyme inhibitors and continuous operation.

- The use of MBR in biofuels, phytotherapics and food ingredients production was analyzed.

\section{A R T I C L E I N F O}

\section{Keywords:}

Membrane bioreactor

MBR

Biorefinery

Biocatalysis

Enzymes in biorefinery

\begin{abstract}
A B S T R A C T
In this review, for the first time, the conjugation of the major types of enzymes used in biorefineries and the membrane processes to develop different configurations of MBRs, was analyzed for the production of biofuels, phytotherapics and food ingredients. In particular, the aim is to critically review all the works related to the application of MBR in biorefinery, highlighting the advantages and the main drawbacks which can interfere with the development of this system at industrial scale. Alternatives stıategies to overcome main limits will be also described in the different application fields, such as the use of biofunctionalized magnetic nanoparticles associated with membrane processes for enzyme re-use and membrane cleaning or the membrane fouling control by the use of integrated membrane process associated with MBR.
\end{abstract}

\section{Introduction}

Biorefineries are based on a wide range of technologies able to transform biomass into its simpler components (proteins, sugars, tryglycerides, etc), which can be further converted into biofuels and other chemicals. On the basis of the feedstock use, it is possible to classify biorefineries in different generations. In the first generation, the main feedstocks are starch- or sugar-based materials: sugarcane, corn, wheat, barley, sorghum, and sunflower.

Although the high content of sugars permits high production of biofuels there is competition with food and feed industries for land use and exploitation (Singh et al., 2019). Second generation biorefinery are biofuels produced from non-food crops processing (forage, bagasse, solid waste, animal fat, wheat straw, rice straw, bagasse, cotton stalk, wheat bran, etc), and are mainly composed of lignocellulosic materials. Together with biofuel, the products could be also high added value compounds. Compared to the first generation, the second generation biorefineries is considered more eco-friendly, more cost-effective and more compatible with the societal development, since it does not exploit food resources. The third generation biorefinery concerns biofuels and biochemicals production from algal biomass (microalgae, cyanobacteria and macroalgae)(Enamala et al., 2018). The great advantages of this biomass are: independence of seasonal growth, high productivity, low $\mathrm{CO}_{2}$ emission (Aguilar et al., 2018), no use of pesticides and herbicides 
in the cultivation (Ahamed \& Vermette, 2008) etc. However, there are some limitations, such as high cost for cultivation and harvesting, which compromises the development at industrial scale. Life cycle analysis (LCA) studies (Cai et al., 2018) have demonstrated that in the first generation biorefineries there is a reduction in greenhouse gas enission and fossil energy consumption, but as far as the industrial development is concerned the second generation biorefineries is more appropriate, because it is more eco-friendly, not in competition with food and cost effective. This is the reason why this review is mainly focused on second generation biorefineries.

The different steps required for the biorefinery are: harvesting, milling and crashing, transformation, separation and formulation. Membrane processes are used in many of the above mentioned steps. However, our review will focuse on transformation and separation promoted by biocatalyst and nembrane separation in membrane bioreactors (MBR). MBRs in biorefineries can pronote enzymes re-use, removal of enzyme inhibitors, continuous operation with a subsequent increase in conversion and enzyme stability. The ain of this review is to show the potential of MBR in biorefinery, highlighting drawbacks which can limit its developmend on industrial scale, but also the innovative strategies, which seem very promising in controlling membrane fouling, enzyme re-use and stability, inhibition product removal and process integration. To reach this aim, a brief overview of MBR technology will be given, followed by the main applications of it in different sectors of biorefinery.

\subsection{Integration of biocatalyst and membrane operations in MBR}

A membrane bioreactor is a merged process, which combines a membrane operation and biocatalysis. In MBR, the membrane can have a catalytic function being the site where the biochenical reaction occurs (biocatalytic menbrane reactor, BMR) or non-biocatalytic function where it only perform the separation process (MBR) (Giorno \& Drioli, 2000; Giomo et al., 2009). In the case of BMR, the membrane itself is catalytic with the biocatalyst being immobilized within the membrane pores. (Mazzei et al., 2017b). On the basis of the membrane module location, external or internal to the reaction mixture, MBRs can be classified in side-stream or submerged configuration (Fig. 1), respectively. In both configurations, the biocatalyst can be free or inmobilized, and the strategy to supply feed and withdraw product can be either continuous and/or intermittent. Several types of membranes and membrane processes can be combined with bioconversions (Table 1). Membranes made of organic polymers, inorganic materials, mixed matrix components, with hydrophilic or hydrophobic character can be used (Drioli \& Giomo, 2020). Symmetric or asymmetric strucures, flat-sheet, spiral-wound, tubular or capillary configuration are suitable in developing MBR. Separation based on sieving mechanism (nicrofiltration, MF; ultrafiltration, UF) also combined with Donnan exclusion (nanofiltration, NF), or solution-diffusion (forward osnosis, FO; pervaporation, PV), partition coefficient (nembrane based solvent extraction, MBSX); membrane emulsification, ME), evaporation (membrane distillation, MD) can be combined with the biocatalysis (Giomo \& Drioli,

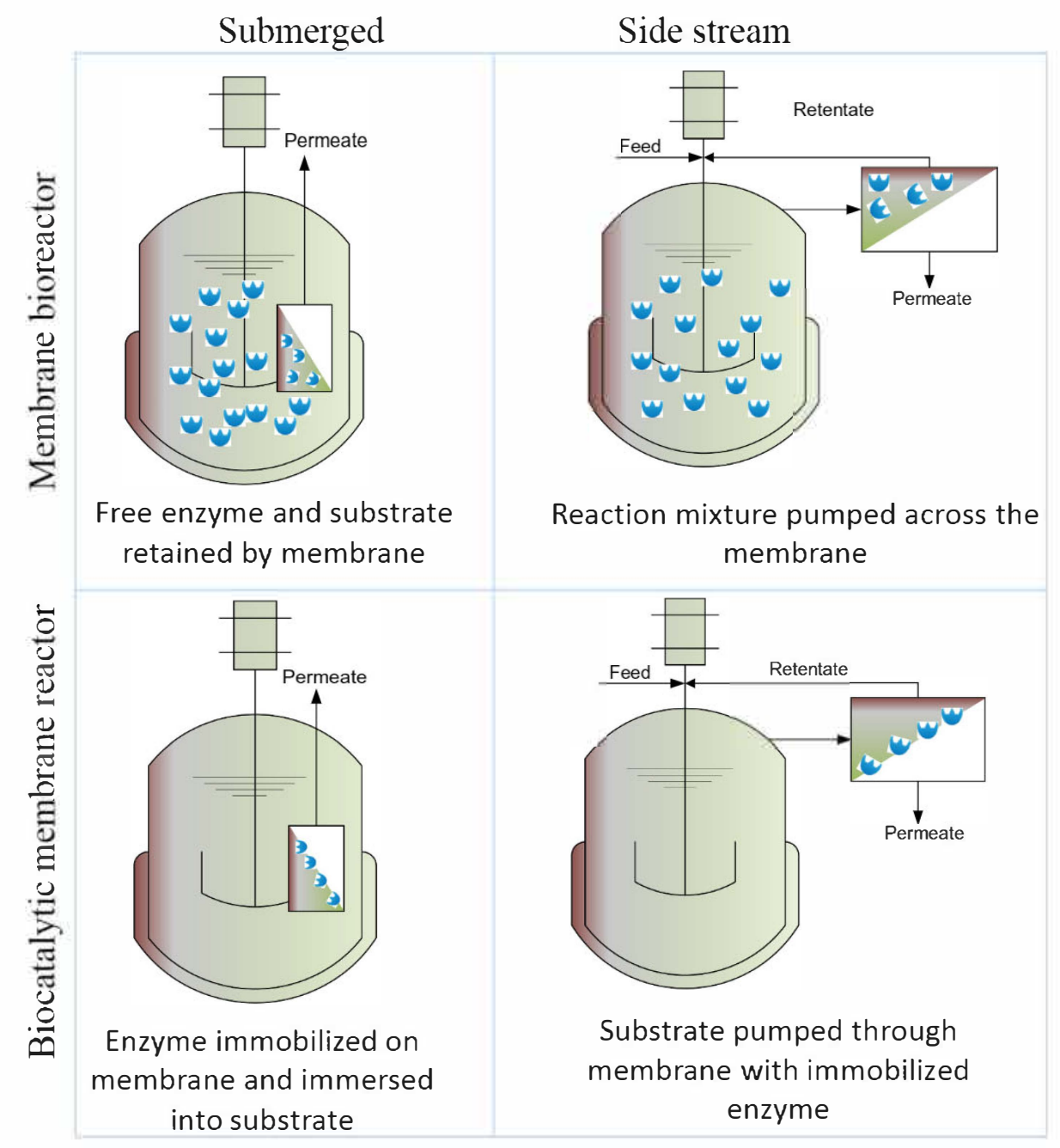

Fig. 1. Schematic representation of membrane bioreactor (MBR) and biocatalytic membrane reactor (BMR) in side-stream and submerged configuration. In the MBR the enzyme is free, while in the BMR the enzyme is inmobilized. 
Table 1

Membranes and membrane reactors in combination with enzymes in biorefinery.

\begin{tabular}{|c|c|c|c|c|c|}
\hline Type of membrane & $\begin{array}{l}\text { Membrane } \\
\text { process }\end{array}$ & Role of membrane & Biocatalyst form & Type of Reactor & Ref. \\
\hline \multirow[t]{3}{*}{ Porous, hydrophilic } & \multirow[t]{3}{*}{ MF } & \multirow[t]{3}{*}{$\begin{array}{l}\text { Retain /recycle biocatalyst } \\
\text { (microorganism, enzyme).Clarify } \\
\text { stream }\end{array}$} & Free bacteria & $\begin{array}{l}\text { Cell-recycle } \\
\text { Membrane Bio- } \\
\text { Reactor (MBR) }\end{array}$ & $\begin{array}{l}\text { (Choudhury \& Swaminathan, 2006; Giorno } \\
\text { et al., 2002) }\end{array}$ \\
\hline & & & $\begin{array}{l}\text { Enzyme } \\
\text { immobilized on } \\
\text { particles }\end{array}$ & $\begin{array}{l}\text { Enzyme-loaded- } \\
\text { particles recycle } \\
\text { MBR }\end{array}$ & (Chang, 2018) \\
\hline & & & $\begin{array}{l}\text { Enzyme } \\
\text { immobilized on } \\
\text { membrane }\end{array}$ & $\begin{array}{l}\text { Biocatalytic } \\
\text { Membrane Reactor } \\
\text { (BMR) }\end{array}$ & $\begin{array}{l}\text { (Giorno \& Drioli, 2000, 2009; Giorno; et al., } \\
\text { 2017; Mazzei et al., 2017a, 2013) }\end{array}$ \\
\hline \multirow[t]{3}{*}{$\begin{array}{l}\text { Mesoporous, } \\
\text { hydrophilic }\end{array}$} & \multirow[t]{3}{*}{ UF } & \multirow{3}{*}{$\begin{array}{l}\text { Retain / recycle } \\
\text { biocatalystRemove inhibitors, } \\
\text { products }\end{array}$} & Free enzyme & $\begin{array}{l}\text { Enzyme-recycle } \\
\text { MBR }\end{array}$ & $\begin{array}{l}\text { (Giorno; et al., 2017) (Drioli \& Giorno, 2009; } \\
\text { Mazzei et al., 2013) (Vitola et al., 2017) }\end{array}$ \\
\hline & & & Immobilized & Enzyme-loaded & (Giorno \& Drioli, 2000; Giorno; et al., 2017) ( \\
\hline & & & enzyme & BMR & $\begin{array}{l}\text { Drioli \& Giorno, 2009; Mazzei et al., 2013) ( } \\
\text { Giomo et al., 2006) (Vitola et al., 2017) }\end{array}$ \\
\hline \multirow[t]{2}{*}{$\begin{array}{l}\text { Microporous, } \\
\text { hydrophilic }\end{array}$} & \multirow[t]{2}{*}{$\mathrm{NF}$} & \multirow[t]{2}{*}{$\begin{array}{l}\text { Fractionate, separate small } \\
\text { molecular weight molecules }\end{array}$} & $\begin{array}{l}\text { Free enzyme, } \\
\text { immobilized } \\
\text { enzyme }\end{array}$ & $\begin{array}{l}\text { Enzyme-recycle } \\
\text { MBR }\end{array}$ & (Chon et al., 2012) \\
\hline & & & $\begin{array}{l}\text { Immobilized } \\
\text { enzyme }\end{array}$ & $\begin{array}{l}\text { Enzyme-loaded } \\
\text { BMR }\end{array}$ & (Dizge et al., 2018) \\
\hline $\begin{array}{l}\text { Porous, mesoporous, } \\
\text { hydrophilic, } \\
\text { hydrophobic }\end{array}$ & MBSX & $\begin{array}{l}\text { Assist/implement interfacial } \\
\text { reactions in biphasic systems. } \\
\text { Extract molecules }\end{array}$ & $\begin{array}{l}\text { Immobilized } \\
\text { enzyme }\end{array}$ & $\begin{array}{l}\text { Enzyme-loaded } \\
\text { BMR }\end{array}$ & (Giorno et al., 2007; Sakaki et al., 2001) \\
\hline Porous, hydrophobic & MD & Concentrate molecules & $\begin{array}{l}\text { Free bacteria } \\
\text { Free enzyme }\end{array}$ & $\begin{array}{l}\text { Cell-recycle MBR } \\
\text { Enzyme-recycle } \\
\text { MBR }\end{array}$ & (Goh et al., 2015) \\
\hline Dense, hydrophilic & $\begin{array}{l}\text { Forward Osmosis } \\
\text { (FO) }\end{array}$ & Concentrate molecules & $\begin{array}{l}\text { Free bacteria } \\
\text { Free enzyme }\end{array}$ & $\begin{array}{l}\text { Cell-recycle MBR } \\
\text { Enzyme-recycle } \\
\text { MBR }\end{array}$ & (Holloway et al., 2015; Song \& Liu, 2019) \\
\hline Dense,Hydrophilic & Pervaporation (PV) & Separate product, remove water & $\begin{array}{l}\text { Free bacteria } \\
\text { Free enzyme } \\
\text { Free enzyme }\end{array}$ & $\begin{array}{l}\text { Cell-recycle MBR } \\
\text { Enzyme-recycle } \\
\text { MBR } \\
\text { Enzyme-recycle } \\
\text { MBR }\end{array}$ & (Fan et al., 2016) \\
\hline $\begin{array}{l}\text { Porous, hydrophilic, } \\
\text { hydrophobic }\end{array}$ & $\begin{array}{l}\text { Membrane } \\
\text { Emulsification } \\
(\mathrm{ME})\end{array}$ & $\begin{array}{l}\text { Enzyme distribution at } \mathrm{O} / \mathrm{W} \text { or } \mathrm{W} / \\
\mathrm{O} \text { interface on droplets/particles } \\
\text { surface } \\
\text { Solvent extraction via high } \\
\text { throughput droplets formation }\end{array}$ & $\begin{array}{l}\text { Immobilized } \\
\text { enzyme }\end{array}$ & $\begin{array}{l}\text { Enzyme-loaded- } \\
\text { particles recycle } \\
\text { MBR } \\
\text { Enzyme-loaded } \\
\text { BMR }\end{array}$ & (Mazzei et al., 2010; Piacentini et al., 2021) \\
\hline
\end{tabular}

2009).

MF and UF using porous $(0.1-10 \mu \mathrm{m})$ and mesoporous $(2-10 \mathrm{~nm})$ membranes, respectively, are often used in combination with biocatalysis for continuous production of valuable compounds and/or treatment of streams. Continuous menbrane fermentors or cell recycle membrane bioreactors are applied when the reaction involves bacteria that perform the bioconversion during the growing phase and/or large size substrates that would not be able to enter the porous matrix (Chang et al., 1994; Giorno et al., 2002). In these cases, the membrane retains the biocatalyst and the large size substrate whilst it permeates the small size products. Examples of application of these systenı include the production of carboxylic acids by fermentation of Lactobacillus bulgaricus (Choudhury \& Swaminathan, 2006; Giorno et al., 2002; Giorno et al., 2017). In cases where the bioconversion of large size substrate macromolecules is catalyzed by enzymes in order to retain it by MF or $\mathrm{UF}$, it is necessary to enlarge its size, which is often obtained by immobilizing enzymes on nanoparticles (Chang, 2018). If the substrate is small enough to enter the membrane pores, then, the biocatalyst (bacteria in vegetative stage or enzymes) can be inmobilized within porous matrices and the reaction occurs within the pore void volume (Giorno \& Drioli, 2000; Giorno; et al., 2017). Examples of application of this configuration in biorefinery, include production of valuable compounds and energy vectors (Drioli \& Giorno, 2009; Mazzei et al., 2013). The inmobilization of enzyme in membranes demonstrated to increase enzyme stability (Giorno \& Drioli, 2000) without necessarily affecting the enzyme catalytic activity (Mazzei et al., 2012), supposed that the microenvironment is tuned to guarantee suitable enzyme macromolecular flexibility and rigidity, water activity (Vitola et al., 2017), substrate mass transport (Giorno et al., 2006).

NF (using membranes with $0.5-2 \mathrm{~nm}$ ) is usually combined with biocatalysis carried out by free enzymes and it is used to fractionate small molecular weights intermediates (Tay et al., 2018). However, some exanple of enzyme inmobilized on NF membranes was also reported (Dizge et al., 2018). Applications include fractionation of oligosaccharides, peptides, amino acids, organic acids.

MDSX is applied to carry out bioconversions using interfacial biocatalysts (such as lipases) immobilized within the menbrane where the organic/water interface is also located (Giorno et al., 2007). Field of applications include production of active ingredients (Sakaki et al., 2001), processing of vegetable oils.

MD and FO are mainly used for concentration of biocatalyst or molecules upstream the membrane (Goh et al., 2015; Holloway et al., 2015; Song \& Liu, 2019). This is usually the case when waters coning from agro-food industries are present in diluted streams that need to be concentrated in order to reduce processing costs. PV is used in combination to bioconversions to separate alcohols fron water-based mixtures (Fan et al., 2016). ME is a relatively novel membrane process able to formulate emulsions on a drop-by-drop mechanism through the membrane pores, which disperse at high throughput, a non-miscible phase into another, at low energy input. ME was proven to be a powerful technique to assist bioconversion by separating reaction product (Mazzei et al., 2010) or by formulating biocatalysts distributed at the interface (Piacentini et al., 2021). 


\section{Use of MBRs in biorefineries}

\subsection{Cellulase and membrane processeses in biorefineries}

The bioprocessing of agro-food residues, such as rice and wheat straws, sugar bagasse and corn stover with $30-50 \%$ of cellulose content, are under intense research and development, with promising results and high technological readiness levels (TRL). Cellulose enzymatic hydrolysis is considered one of the most costly steps in the bioconversion of lignocellulosic biomass (Malmali et al., 2015), which involves an interfacial heterogeneity of solid cellulose substrate and cellulase enzyme adsorption. Various studies confirmed that it is possible, via membrane technology, to retain the enzymes present in the system, while allowing the transfer of lower-molecular weight reaction products to pass through the membrane (Andrić et al., 2010a).

Table 2 is a comprehensive summary of these studies, and major points are discussed in more details below. Most of the cases utilize menbranes with molecular weight 10-50 kDa cut-off i (Table 2). Usually, the reaction mixture of the substrate and enzyme is recirculated in the membrane reactor, whereas a stream with the products is withdrawn from the permeate side. Flat sheet membranes in a side-stream configuration are prevalently used. Only in few systems, a submerged membrane hollow fiber configurations, which can be more beneficial in terms of fouling control, are used.

Major challenges that limits industrial scale MBRs for cellulose hydrolysis include low substrate concentration, enzyme microbial degradation, and membrane fouling. For example, the cellulose concentration $(2-5 \mathrm{w} / \mathrm{v} \%)$ is considered low for industrial application as it leads to low glucose concentration in the permeate (Malmali et al., 2015; Nguyenhuynh et al., 2017).

\subsubsection{Discontinuous MBR and product inhibition}

During cellulose hydrolysis, although a $100 \%$ yield is expected due to enzyme specificity, most batch reactions could not achieve this, due to enzyme product-inhibition. The inhibition of cellulolytic enzymes by glucose, cellobiose (Berlin et al., 2007), which are produced during saccharification (Cantarella et al., 2014; Ximenes et al., 2011), released during lignocellulosic pretreatment, is a well-known problem. This is exacerbated by the high enzyme cost, imparted by its dischargment and replacement. The cellulase enzyme replacement contributes up to $20 \%$ of the total cost in case of bioethanol production and $\sim 50 \%$ of the entire hydrolysis step, liniting both the technological and economic feasibility of the hydrolysis process. A detailed analysis of the mechanisns and kinetics of the product-inhibition of cellulolytic enzymes by glucose and cellobiose has confirmed that reactors should be designed with continuous or semi-continuous product removal. As a result, numerous studies have focused on the integration of membrane bioreactors (MBRs) in biorefineries for simultaneous hydrolysis and continuous/intermittent in-situ product removal (Gebreyohannes et al., 2013; Mahboubi et al., 2017b; Nguyen et al., 2015).

In this section we will discuss major research findings using intermittent/discontinuous processes. A four-fold increase in enzymatic hydrolysis of cotton cellulose with internittent removal of the product cellobiose, by using a flat-sheet polyethersulfone membrane was achieved (Gavlighi et al., 2013). Authors achieved 19\% degree of conversion after 3 days, for a reasonable feed concentration of $25 \mathrm{~g} / \mathrm{L}$.

The hydrolysis of microcrystalline pure cellulose powder was also evaluated in a tubular MBR configuration and compared with a flatsheet MBR (Bélafi-Bakó et al., 2006). 95\% of the cellulase was retained by membrane as estimated by dry weight measurements and only $6 \%$ of the initial enzyme activity has been observed in the permeate. Thus, the membrane sufficiently retained both the substrate and enzyme. Possibly, due to better mass transfer, the tubular membrane gave $10 \%$ higher average conversion than the flat-sheet membrane configuration. In another MBR (Liu et al., 2011) configuration the cellulase from Aspergillus niger was free in solution and retained in the
MBR by a polyethersulfone ultrafiltration membrane. Also in this system a complete retention of both cellulose and cellobiase was observed.

In a recent study, a modified submerged MBR for enzynatic cellulose hydrolysis was developed (Nguyenhuynh et al., 2017). In this work the intermittent product removal was used and in the mentioned conditions more effective UF perfornuance with complete glucose permeation and enzyme retention up to $80 \%$ was obtained.

Qi et al. (Qi et al., 2012) examined the application of combined UF and NF for recovering the cellulase and concentrating glucose, respectively, in an integrated approach. They found that the UF membranes pernitted a cellulase retention of $74 \%$, a conversion of $84.5 \%$ and a recovery of all the glucose in the permeate.

Although UF based MBR was effective to retain the enzyme and limit enzyme product inhibition, the system was prone to membrane fouling. As a strategy to limit membrane fouling, Lim and Ghazali (2020) used an intermittent product removal during the continuous hydrolysis of microcystalline cellulose. The removal of the product from the bioreactor using UF membrane filtration was done under two different strategies. For Strategy 1, 50\% of the reaction mixture was filtered after $4 \mathrm{~h}$ of hydrolysis reaction to remove the reducing sugar. The recycling of the enzyme and the filtration of the hydrolysate were carried out simultaneously. The hydrolysis reaction was continued and the filtration was repeated at the 8 th $\mathrm{h}$. For Strategy 2, the fresh substrate and citrate buffer were added at a $24 \mathrm{~h}$ interval, while the filtration process started at the 24 th $\mathrm{h}$.

Compared to the batch productivity (63\% of cellulose conversion after $72 \mathrm{~h}$ ), the intermittent product removal gave a 10x times higher productivity, due to the linited enzyme-product inhibition. The more frequent product removal, together with the enzyme recycling, was sufficient to main a reasonable reactor productivity. Table 2 also shows that most of the systems utilized side-stream MBR configuration, which enforces pumping a slurry. Recently, there is a growing effort and success in the use of submerged MBR in order to resolve this issue. A modified submerged MBR system with internittent product removal developed recently for instance gave an effective UF performance with complete glucose permeation and up to $80 \%$ enzyme retention (Nguyenhuynh et al., 2017).

In another approach, the hydrolysis of $\alpha$-cellulose was carried out in a submerged continuous MBR. Since an MF membrane was used in the submerged system, a pre-holding time was allowed in order to promote a better binding between enzyme and substrate (Malmali et al., 2015). The continuous hydrolysis with in-situ product removal gave an order of magnitude higher rate of glucose production relative to batch process, due to enzyme product-inhibition. On the other hand, the biocatalysis of carboxymethyl cellulose in an MBR equipped with MF and enzyme immobilized on magnetic nanoparticles led to a constant reaction rate over time, and $50 \%$ higher enzyme efficiency, due to in-situ product removal (Gebreyohannes et al., 2018). The use of biofunctionalized nanoparticles have the inherent issue of nanoparticle aggregation at high concentration. Hence, designing the system under reaction rate limited regine can prevent mass transfer resistance due to particle aggregation and the subsequent loss of biocatalytic efficiency. In addition to in-situ product removal, the use of a cocktail of synergistically performing different cellulytic enzymes can be an effective strategy to reduce the extent of the enzyme-product inhibition (Gebreyohannes et al., 2018; Lozano et al., 2014). When the hydrolysis of carboxymethyl cellulose was run with a mixture of endoglucanase and $\beta$-glucosidase, in an MBR configuration higher monomer to oligomer ratio, was obtained due to absence of cellobiohydrolase and -glucosidase inhibition by cellobiose and the and glucose, respectively (Gebreyohannes et al., 2018). Not only the use of mixture of these enzymes but also an appropriate ratio of cellulase and cellobiase is highly imperative to achieve rapid cellobiose hydrolysis and prevented the cellulase inhibition (Lozano et al., 2014). 
Table 2

Enzymatic hydı $\bullet y s i s$ of cellulose in MBRs.

\begin{tabular}{|c|c|c|c|c|c|c|c|c|c|}
\hline \multirow[t]{2}{*}{ En zyme source } & \multirow[t]{2}{*}{ Enzyme content } & \multicolumn{3}{|l|}{ Membrane } & \multirow[t]{2}{*}{ Feed } & \multirow{2}{*}{$\begin{array}{l}\text { Conversion } \\
(\%) / g \text { lucose mM }\end{array}$} & \multirow{2}{*}{$\begin{array}{l}\text { Feed } \\
\text { concentration }\end{array}$} & \multirow{2}{*}{$\begin{array}{l}\text { Product } \\
\text { concentration }\end{array}$} & \multirow[t]{2}{*}{ Ref. } \\
\hline & & 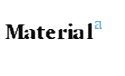 & Type $e^{b}$ & $\begin{array}{l}\text { MWCo } \\
\text { (kDa) }\end{array}$ & & & & & \\
\hline Trichoderma reesei & n.d. & polymeric & HFFs & n.d. 30 & $\begin{array}{l}\text { Microcryst. cellulose } \\
\text { powder }\end{array}$ & $48-53$ & $2.5 \%(\mathrm{w} / \mathrm{v})$ & $3.7-6.5 \mathrm{~g} / \mathrm{h} \mathrm{dm}{ }^{3}$ & (Bélafi-Bakó etal., 2006) \\
\hline Trichoderma reesei & n.d. & PES & FS & 10 & $\begin{array}{l}\text { Oil palm empty fruit } \\
\text { bunch }\end{array}$ & n.d. & $20 \mathrm{~g} / \mathrm{L}$ & $2-4 \mathrm{~g} / \mathrm{L}$ & (Ghazali et al.,2017) \\
\hline Aspergillus niger & $1.5 \mathrm{~g} / \mathrm{L}$ & PES & FS & 10 & $\begin{array}{l}\text { Sodium carboxy } \\
\text { methylcellulose }\end{array}$ & $40-90$ & $1.5 \mathrm{~g} / \mathrm{L}$ & $1.2 \mathrm{~g} / \mathrm{L}$ & (Liu et al.,2011) \\
\hline Trichoderma reesei & n.d & PES & FS & 10 & Microcryst. cellulose & 80 & $5-20 \mathrm{~g} / \mathrm{L}$ & $4.4-12.2 \mathrm{~g} / \mathrm{L}$ & (Lim \&Ghazali, 2020a) \\
\hline Trichoderma reesei & $1.36 \mathrm{~g} / \mathrm{L}$ & PES & FS & 10 & Microcrystalline cellulose & 80 & $10 \mathrm{~g} / \mathrm{L}$ & $5.48-6.45 \mathrm{~g} / \mathrm{L}$ & (Lim \&Ghazali, 2020b) \\
\hline Cellic Ctec2 & n.d. & PES & FS & $0.3 \mu \mathrm{m}$ & $\begin{array}{l}\text { Dilute-acid pretreated } \\
\text { wheatstraw }\end{array}$ & $70-80 \%$ & $14.0 \mathrm{~g} / \mathrm{L}$ & $14.65=0.59 \mathrm{~g} / \mathrm{L}$ & (Mahboubi et al., 2020) \\
\hline n.d. & $3 \% \mathrm{w} / \mathrm{w}$ enzyme to substrate ratio & PES & FS & 10 & Microcryst. cellulose & n.d. & $10 \% \mathrm{w} / \mathrm{v}$ & $7.6 \mathrm{~g} / \mathrm{L}$ & $\begin{array}{l}\text { (Nguyenhuynh et al., } \\
\text { 2017) }\end{array}$ \\
\hline n.d. & $\begin{array}{l}0.7 \mathrm{~g} / \mathrm{l} \text { of }(x \text { - amylase and } 0.42 \mathrm{~g} / \mathrm{l} \text { of } \\
\text { amyloglucosidase }\end{array}$ & $\begin{array}{l}\text { PDMS/ } \\
\text { PET/PI }\end{array}$ & FS & n.d. & Broomcorn seed flour & n.d. & $45 \mathrm{~g} / \mathrm{l}$ & $25.5 \mathrm{~g} / \mathrm{L}$ & (Farali i et al., 2018) \\
\hline n.d. & $0.5 \mathrm{~g} / \mathrm{L}$ & PES & FS & 10 & $\alpha$-cellulose & 45 & $10 \mathrm{~g} / \mathrm{L}$ & $2-8 \mathrm{~g} / \mathrm{L}$ & (Abels et al.,2013) \\
\hline $\begin{array}{l}\text { Trichoderma reesei } \\
\text { in.d. }\end{array}$ & $\begin{array}{l}4 \mathrm{~g} / \mathrm{L} \\
20 \mathrm{FPU} / \mathrm{g} \text { cellulose }\end{array}$ & $\begin{array}{l}\mathrm{ZrO}_{2} \\
\mathrm{PES}\end{array}$ & $\begin{array}{l}\text { FS } \\
\text { FS }\end{array}$ & $\begin{array}{l}10 \\
51030\end{array}$ & $\begin{array}{l}\text { Olive mill solid residue } \\
\text { Steame exploded wheat } \\
\text { straw }\end{array}$ & $\begin{array}{l}45 \\
84.5\end{array}$ & $\begin{array}{l}\text { n.d. } \\
10 \% \text { w } / v\end{array}$ & $\begin{array}{l}2-11 \mathrm{~g} / \mathrm{L} \\
26.5-30.4 \mathrm{~g} / \mathrm{L}\end{array}$ & $\begin{array}{l}\text { (Mameri et al.,2000) } \\
\text { (Qi et al., 2012) }\end{array}$ \\
\hline Trichoderma reesei & 20 to $80 \mathrm{mg} / \mathrm{g}$ substrate & PES & FS & 5 & Waste paper & 67.4 & $20-100 \mathrm{~g} / \mathrm{L}$ & $12-50 \mathrm{~g} / \mathrm{L}$ & (Rad et al. 2017) \\
\hline Trichoderma reesei & $20 \mathrm{FPU} / \mathrm{g}$ substrate & PS & $\mathrm{HF}$ & 10 & $\begin{array}{l}\text { Steam-exploded rice } \\
\text { straw }\end{array}$ & n.d. & $125-185 \mathrm{~g} / \mathrm{L}$ & $15-35 \mathrm{~g} / \mathrm{L}$ & (Yang et al.,2006) \\
\hline $\begin{array}{l}\text { Trichoderma } \\
\text { longibrachiatum }\end{array}$ & $20 \mathrm{FPU} / \mathrm{g}$ dry mass & PES & FS & $-\mathrm{DF} 20-10$ & acid treated wheat straw & $50.3(\%)$ & $0.5-10 \%$ & n.d. & (Chen et al., 2013) \\
\hline Crude cellulase powder & & PS & $\mathrm{HF}$ & 30 & $\begin{array}{l}\mathrm{CO}_{2} \text { laser treated com } \\
\text { Stover }\end{array}$ & & & & $\left(\right.$ Chen et al.,2013) ${ }^{\mathrm{c}}$ \\
\hline Trichodermareesei & & PC & & $/ 0.22 \mu \mathrm{mI}$ & $\begin{array}{l}\text { carboxymethyl cellulose } \\
\text { (CMC) }\end{array}$ & $54(\%)$ & $20 \mathrm{~g} / \mathrm{L}$ & $0.5-2 \mathrm{~g} / \mathrm{L}$ & (Nguyen et al.,2015) \\
\hline Novozyme cellulase & $317.24 \mathrm{mg}$ prote ins $/ \mathrm{mL}$ & - & - & 10,20 & $\begin{array}{l}\text { carboxyme thyl cellulose } \\
\text { (CMC) }\end{array}$ & 1 - & $2.5 \mathrm{~g} / \mathrm{L}$ & n.d. & (Cantare lla et 2014) \\
\hline Trichoderma reesei & & PS & & 10 & Pretreatd com stover & (continuous) & $15 \mathrm{~g} / \mathrm{L}$ & $10-30 \mathrm{~g} / \mathrm{L}$ & (Zhang et al.,2011) \\
\hline Trichoderma reesei & & PVDF & FS & $0.2 \mu \mathrm{m}$ & Carboxymethyl cellulose & 10.9 & $0.5 \mathrm{wt} \%$ & $90-160 \mathrm{mg} / \mathrm{L}$ & $\begin{array}{l}\text { (Gebreyohamneset al., } \\
2018 \text { ) }\end{array}$ \\
\hline Cellic CTec2 & & PES & FS & $0.62 \mu \mathrm{m}$ & $\alpha$-cellulose & $/ 0.08-0.11$ & $100-150 \mathrm{~g} / \mathrm{L}$ & $40-100 \mathrm{~g} / \mathrm{L}$ & (Malmali et al.,2015) \\
\hline Trichoderma reesei & & PES & TUBULAR & 10 & microcrystalline cellulose & $/ 113$ & $0.8-2 w / v \%$ & $19.8 \mathrm{~g} / \mathrm{L}$ & (Lozano et al.,2014) \\
\hline
\end{tabular}

n.d., no data available in most cases, $\mathrm{pH} 4.8-5.0$ and temperature $40-50^{\circ} \mathrm{C}$

a PES: polyethersulfone; PAN: polyaciylonitrile; PA: polyamide; PS: polysulfone; PC: polycarbønate.

b FS, flat-sheet; HF, hollow fiber 


\subsubsection{Continuously fed MBR, limitation to low MWCO membrane and operational conditions}

As shown in Table 2, most MBRs for cellulose hydrolysis are operated with a separated bioreactor and pumping of the slurry across the membrane for ultimate retention/recycling of the unreacted substrate and enzyme, while allowing permeation of glucose. In order to retain the $60 \mathrm{kDa}$ cellulase enzyme (Suurnäkki et al., 2000), the membrane molecular weight cut-off used in this application is often limited to about 10 kDa (Giorno \& Drioli, 2000; Tian et al., 2015). Andrić et al. (2010b) have previously indicated that an appropriate MBR design for continuous enzymatic hydrolysis with in-situ product removal is crucial. However, a side-stream configuration is a limiting factor to successful large scale applications, since pumping a slurry imparts a significant operating cost (Roche et al., 2009; Stickel et al., 2009). Moreover, low MWCO membranes require high transmembrane pressure and leads to significant membrane fouling (Lim \& Ghazali, 2020; Lozano et al., 2014; Mahboubi et al., 2017a). While a continuously fed MBR could face severe membrane fouling, owing to the enzyme retention and simultaneous product removal, a continuously/intermittently fed system can have better productivity.

For instance, a corn stover pre-treated by soaking in $15 \mathrm{wt} \%$ aqueous ammonia incubated with a cellulase loading of $60 \mathrm{FPU}$ per initial cellulose was used to compare the performance difference among batch, continuously fed and intermittently fed MBR. Intermittent addition of 5 g/L cellulose every $8 \mathrm{~h}$, gave a total glucose of 1.94 and 1.88 times higher than batch reactor without MBR and continuously fed MBR, respectively.

Yet, the obtained product concentration in many of the studies is considerably low (0.2-20 g/L,) (Gebreyohannes et al., 2018; Lim \& Ghazali, 2020; Lozano et al., 2014; Zhang et al., 2011). Since the desired concentration for subsequent fermentation to ethanol, falls between 150 and $250 \mathrm{~g} / \mathrm{L}$ glucose (Malmali et al., 2015), a significant energy is consumed in pre-concentration. Increasing the substrate concentration specially when using high MWCO membrane can be one strategy to achieve a higher product concentration (Malmali et al., 2015).

In all these discussions, it was difficult to elucidate the contribution of the enzyme, as the type, amount and units of the enzymes used were different.

Various strategies have been employed to alleviate the issue of membrane fouling. A good example could be application of electroultrafiltration (EUF) during the filtration of pre-hydrolyzed acid pretreated wheat straw to mitigate the membrane fouling. EUF is a method, where a differential electric field is applied across the membrane to achieve electrostatic repulsion of membrane foulants (Hakimhashemi et al., 2012). The flux when the system was fed with $2 \% \mathrm{w} / \mathrm{v}$ lignocellulosic hydrolyzate increased by a factor of 4.4 at room temperature, compared to that without electric field

Moreover, intensification of the hydrolysis step with the fermentation process in a simultaneous saccharification and fermentation (SSF) seems to be the most promising strategy to increase overall productivity. The potential application of such hybridized system was recently shown by (Mahboubi et al., 2020).

The cellulose hydrolysis using MBR often requires low solid loading or low solid loading rate and continuous dilution in order to reduce the extent of membrane fouling, the enzyme product-inhibition and the difficulty of pumping a concentrated slurry. In order to resolve the issue of pumping slurry, a submerged MBR with a $10 \mathrm{kDa}$ UF membrane was designed. Although the UF membrane was successful in retaining the enzyme (97\%) and avoided pumping slurry, the cost for the pressurized reactor is considerable, while the membrane fouling was still severe (Zhang et al., 2011).

Alternatively, a submerged MBR integrating an MF membrane was employed (Malmali et al., 2015), which avoids pumping cellulose slurry. Owing to the use of MF, a high initial cellulose loading (100 and $150 \mathrm{~g} /$ L) was used, which are significantly higher than the cellulose loading observed in most MBRs (see Table 2). Higher substrate loading ensured higher glucose concentration; hence, the steady-state glucose concentration was $10-15 \mathrm{~g} / \mathrm{L}$. These values are significantly higher than the concentration obtained in the various UF systems. One of this systems' disadvantages is enzyme loss through the membrane. However, the extent of enzyme loss was limited by the introduction of pre-holding time that provided sufficient time for the enzyme to attach onto the cellulose. As a result, compared to the very high initial enzyme loading (50 $\mathrm{mg} / \mathrm{g}$ cellulose), the rate of enzyme addition during continuous operation was either 4 or $10 \mathrm{mg}$ enzyme/g cellulose injected. In addition, the use of higher cellulose loading ensured more enzyme retention.

\subsubsection{Biocatalytic membrane reactors in cellulose hydrolysis}

Commercial cellulase enzyme is often a cocktail of cellulolytic enzymes that include endo/exo glucanase, cellobiohydrolase and $\beta$-glucosidase. However this mixture generally exhibits low $\beta$-glucosidase activity (Rosgaard et al., 2006). Therefore, the hydrolysis by endoglucanase mainly favors the production of oligomers such as cellobiose and cellotriose. As a result, Gebreyohannes, Dharmieet (Gebreyohannes et al., 2018) for instance obtained 50-60\% higher oligomer productivity than monomers when using an MF membrane systen with immobilized enzyme. Over production of cellobiose on the one hand causes enzyme product inhibition, while on the other hand it may cause loss of significant amount of it to the permeate. In order to limit this problem, it is imperative to supplement the system with additional $\beta$-glucosidase (Andrić et al., 2010b). Especially co-inmobilization of these enzymes in a biocatalytic membrane reactor (BMR) configuration is highly beneficial. Accordingly, both Gebreyohannes et al. (2018) and Song et al. (2016a) observed a significantly improved monomer productivity by coimmobilization of cellulase and $\beta$-glucosidase in a BMR ( 4 times higher) and STR respectively. Enzyme immobilization is also a good strategy to shift from UF membrane based MBRs to MF based BMRs that will eventually ensure a higher volumetric reactor productivity.

For instance, the natural tendency of enzyme to be adsorbed by cellulose, often a concern for enzyme efficiency loss, was taken as an advantage in order to retain the enzyme in $0.6 \mu$ MF equipped submerged MBR for cellulose hydrolysis. While this system requires significant pre-holding time in order to ensure sufficient adsorption, the loss of enzyme is still unavoidable

In this case, membranes with immobilized enzyme in BMR configuration can be beneficial. Although the issue of enzyme leakage can be resolved through confining the enzyme on to the membrane or carrier particle, BMRs are less often used (Andrić et al., 2010a). However, since enzyme immobilization can contribute to the development of sustainable processes, it has substantial potential to be used in industrial lignocellulose-to-ethanol conversion. (Chang et al., 2011; Rodrigues et al., 2017)

A very recent strategy of biocatalytic systems is to immobilize enzymes on superparamagnetic nanoparticles $\left(\mathrm{NP}^{\mathrm{SP}}\right)$. These particles afterwards are reversibly immobilized on a nicroporous membrane using an external magnetic field in a system named superparamagnetic biocatalytic membrane reactor (BMR ${ }^{\mathrm{SP}}$ ) (Gebreyohannes et al., 2015, 2017). The immobilization of the enzyme on the $\mathrm{NP}^{\mathrm{SP}}$ can improved stability, activity along with easy recovery using an external magnetic force. (Ladole et al., 2017; Lupoi \& Smith, 2011; Song et al., 2016b; Xu et al., 2011) Due to the possibility of using MF membrane with immobilized enzyme, it was possible to achieve constant glucose productivity at high solid loading (2-10 wt $\% \mathrm{CMC}$ ), high solid loading rate (3-6 g/h) and negligible rate of fouling ( $0.008 \mathrm{bar} / \mathrm{min})$ in a submerged system. This is an immense improvement of the lignocelluloisic hydrolysis, which is generally limited to UF nembranes to retain the enzymes (Gebreyohannes et al., 2018).

On the basis of the reported studies on enzymatic cellulose hydrolysis, enzyme stability, enzyme turnover, membrane fouling and product concentration still remain open challenges. The reactor design must be fully considered, particularly to limit the enzyme cost, which contributes 25-30\% operational cost (Guo et al., 2018). Side-stream MBR 
configuration, which combines free enzyme carrying out the hydrolysis in bulk and a membrane that removes the reaction products, is by far the most investigated. In this configuration, the enzyme compartimentalization promoted by membrane process, guarantees enzyme re-use and product inhibiton limitation, showing huge potential in operational cost reduction. Since MF can only retain enzymes compartmentalized to membrane or carrier particles, it is less interesting to employ it in a sidestream configuration (Malmali et al., 2015). Over all, use of membrane was effective in retaining the enzyme and preventing enzyme-product inhibition through intermittent/continuous product removal. Though dictated by the frequency of feeding and product withdrawal, this strategy also helps to nitigate membrane fouling. In terms configuration, a hybridization of hydrolysis with fermentation could be a way forward towards industrialization. While a submerged MF equipped MBR with inmobilized enzyme could be an optimal strategy to increase MBRs volunetric productivity.

\subsection{B-gucosidase and membrane process in biorefinery}

$\beta$-glucosidase is a key enzyme in determining efficiency of cellulase for biomass hydrolysis, but recently it has also gained attention for its ability to hydrolyze glycosidic substrates from vegetal biomass to produce aglyconic compounds, which have important therapeutic properties (Mazzei et al., 2012, 2009; Ranieri et al., 2018). The use of

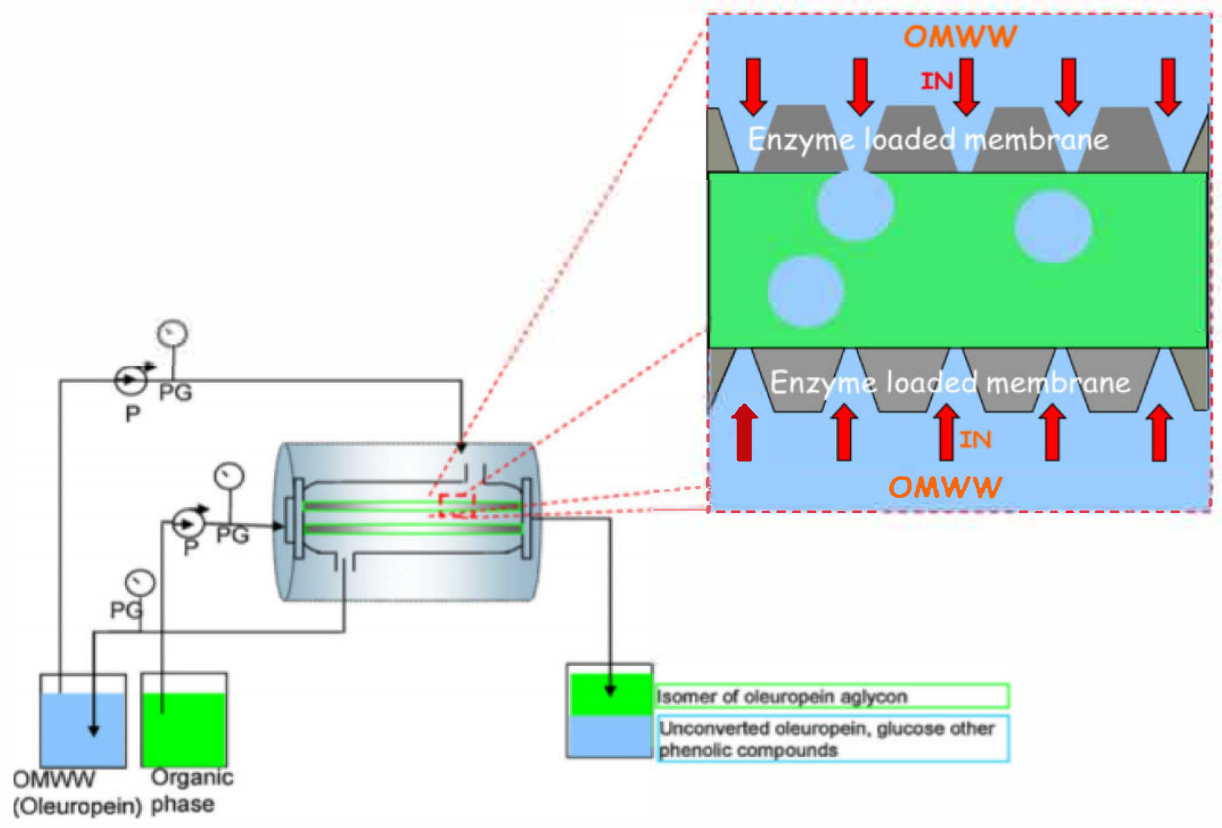

A

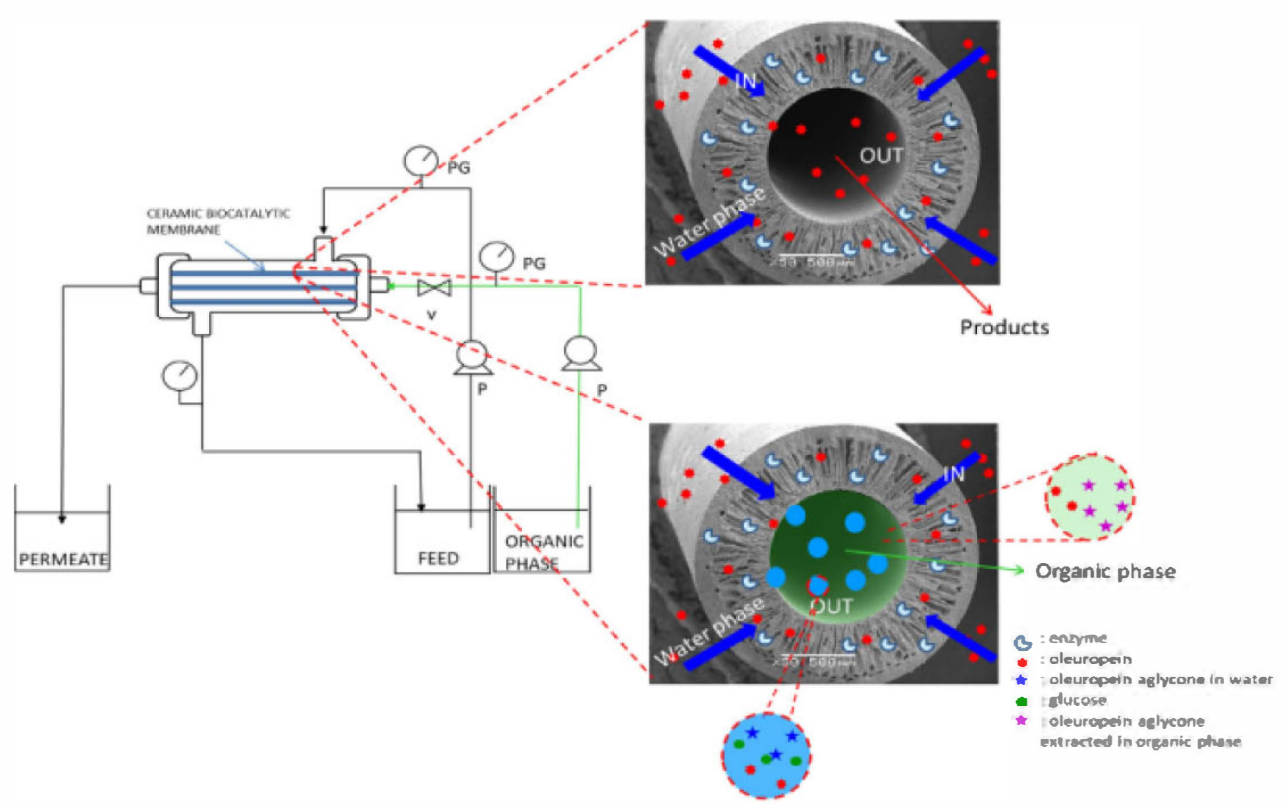

Fig. 2. Intensified membrane processes, in which MBR and membrane emulsification were coupled in a multhipashic system to promote production/extraction (in organic solvent) of aglycone. A: use of commercial polymeric membrane and physical enzyme immobilization, adapted from (Mazzei et al., 2012) with the permission of Copyright (2021) Elsevier; B: use of home-made ceramic membranes and covalent enzyme inmobilization reprinted with permission from (Ranieri et al., 2018) with the permission of Copyright (2021).OA: oleuropein aglycone (product of oleuropein hydrolysis by $\beta$-glucosidase action), OMWW: olive mill waste water. 
menbrane bioreactors in the production of aglyconic compounds solved several problens: the continuous removal of the inhibiton product (glucose) from the reaction site, the extraction of the water unstable aglycones in organic solvents by multhiphasic MBR, (Mazzei et al., 2010) and the enzyme reuse. On the basis of the problen treated (e.g. glucose inhibition, aglycones extraction, kinetic study etc), $\beta$-glucosidase was entrapped on polymeric membranes (Mazzei et al., 2012, 2009) or covalently attached on ceranic membrane (Fig. 2A) (Mazzei et al., 2012)(Fig. 2B)(Ranieri et al., 2018). By using both biocatalytic polymeric and ceramic membranes, it was possible to produce an intensified system, in which the production/extraction of the aglycone in a pure organic solvent was promoted (Fig. 2). In the mentioned system, the aglycone extraction process is obtained by recirculating a pure organic solvent, in which the compound is soluble, in the lumen of a tubular membrane. When the aqueous phase, coning from the biocatalytic membrane and containing the product, it reaches the membrane lumen, on the basis of the membrane enulsification process an unstable enulsion is produced, which permits the aglycone extraction from the aqueous to the organic phase (Mazzei et al., 2010)(Fig. 2 a and b). Due to membrane processes modularity, the intensified MBR/ME system with an MF/UF process (Conidi et al., 2014) or with two steps of membrane enulsification (Piacentini et al., 2019) was easily integrated (Fig. 3). In the first work, olive mill waste water (OMWW) pre-treated by MF/UF steps and containing the glycosidic substrate (oleuropein) was fed to the intensified process, obtaining the same degree of conversion when pure substrate was used (Fig. 3A). In the second system, in addition to the production/extraction of oleuropein aglycone, its encapsulation in hydrophilic polyneric (Fig. 3B) or hydrophobic solid lipid particles (Fig. 3C) was also promoted (Piacentini et al., 2019).

Recently, a further inprovenent of the system in terms of conversion (93\%) by using the enzyme free in solution and promoting aglycone extraction by ME process (Fig. 3D) was obtained (Mazzei et al., 2020). The role of the membrane, in this system, was to retain the enzyme and to wash out the glucose from the reaction mixture. This pernitted to reuse the biocatalyst for five consecutive reaction cycles, with no decay in conversion. In the two last mentioned systens, olive leaves as source of bionass to obtain the glycosidic substrate were used.

\subsection{Xylanase and MBR in biorefineries}

Xylan is the second most abundant renewable compound on earth and a sustainable technology which pernits the recovery/fractionation of xylo-oligosaccharides (XOS) and monosaccharide from xylan is one of the current priorities in the research related to biorefineries. On the basis of the type and content of substituents within the xylan structure, the synergistic action of xylanase (in particular endo-1,4- $\beta$-xylanase and $\beta$-xylosidase) and other debranching enzyme ( $\alpha$-L-arabinofuranosidases, $\alpha$-glucuronosidase, acetyl xylan esterases and ferulic acid esterases) is
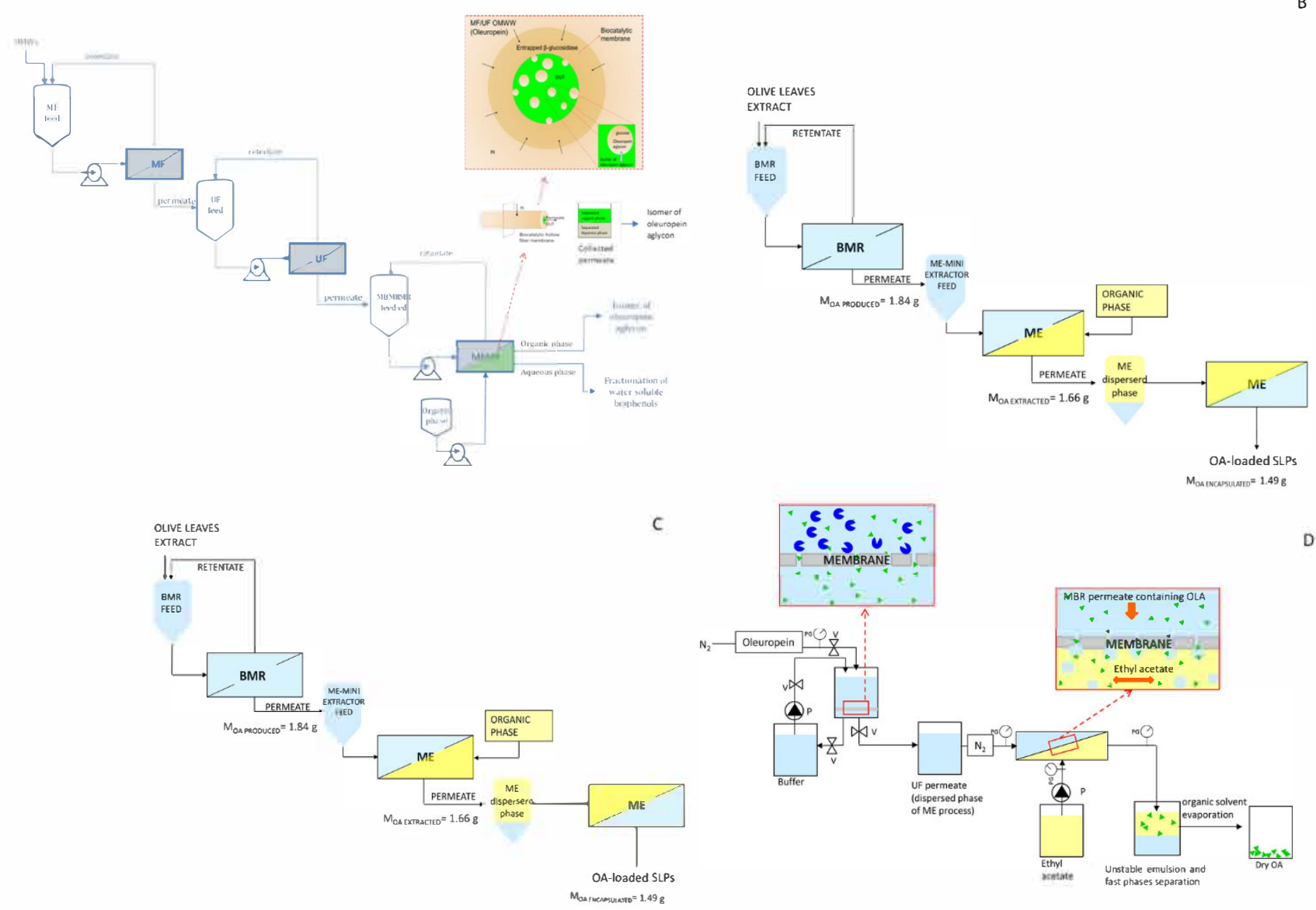

Fig. 3. Multhiphasic membrane bioreactor integrated with different membrane processes for the production of aglycone or formulated aglycone starting from different biomass. A) MBR integration with MF and UF process starting from olive mill waste (OMW). Reprinted with permission from (Conidi et al., 2014). Copyright (2021) Elsevier; B) MBR integration with two steps of membrane enulsification processes to produce solid lipid particles (SLP) containing oleuropein aglycone, starting from olive leaves. Reprinted with permission from (Piacentini et al., 2019). Copyright (2021) American Chemical Society; C) MBR integration with membrane emulsification processes to produce PVA particles containing oleuropein aglycone starting from olive leaves; Reprinted with permission from (Piacentini et al., 2019). Copyright (2021) American Chemical Society D) Integration of MBR with membrane emulsification process to produce aglycone from olive leaves reprinted from (Mazzei et al 2020)(CC-BY 4.0 licence). OA: oleuropein aglycone (product of oleuropein hydrolysis by $\beta$-glucosidase action). 
generally needed. However, due to the product inhibition on the xylanases enzymes a separation step to isolate the biocatalyst is necessary, particularly if a large scale and a continuous process is needed.

A lot of recent articles propose membrane bioreactor technology to overcome the limits given by product inhibition (Andrić et al., 2010a; Nabarlatz et al., 2007; Pinelo et al., 2009; Sueb et al., 2017) and to simultaneously purify the product from the reaction mixture.

However, it must be considered that the substrate tends to accumulate on the menbrane surface as gel-like aggregates, influencing the fluid-dynamic conditions and enzyme kinetic properties.

In the work carried out by Sueb et al. (2017) the effect of fouling due to particle deposition was evaluated by different configuration of MBRs. The MBRs configuration used were: a) reaction (endo-1,4-b-xylanase and $\beta$-xylosidase, free state) and filtration (1 kDa PES membrane) in the same systen; b) xylanase (free state) reaction and filtration in a MBR and a further enzymatic reaction of the permeate by xylosidase in a STR; c) both enzymes present in a stirred tank reactor and a subsequent filtration process. Reaction with both enzynes føllowed by UF (configuration C) was the optinal configuration, which permitted at least $40 \%$ higher xylan hydrolysis than the cascade configuration.

In the work carried out by Acosta-Fernández et al. (2020), a membrane with higher nominal molecular weight cut-off (10 kDa) was used starting from xylan from coffee parchment. In the mentioned research the enzyne free in solution or inmobilized on magnetic nanoparticles, in 2 STRs and in 2 MBRs, were compared. Results demonstrated that by using the MBRs configurations a continuous production of xylooligosaccharides, with the molecular weight distribution in the range of prebiotic sugars (X1 - X20) was obtained. By optimizing the fluiddynanic conditions a high conversion can be also achieved at high substrate concentration. Besides, the unchanged apparent $\mathrm{Km}$ demonstrated that the enzyme immobilization procedure did not alter the af finity of the enzyme for the substrate and it was even improved when membrane process was present, since it promoted a continuous removal of inhibition products from the reaction mixture.

Biofunctionalized magnetic nanoparticles were also coupled to an organic-inorganic hybrid membrane (were magnetic nanoparticles were used as nanofillers) to develop a nano-inspired, magnetic-responsive enzyme membrane (micro) reactor (Gebreyohannes \& Giorno, 2015). In this system xylanase and pectinase as model biocatalysts were used to control membrane fouling. The system permitted $75 \%$ reduction in membrane filtration resistance through the membrane surface cleaning.

An integrated membrane process was also proposed by González Muñoz et al. (2008), in which liquors containing xylan-derived products from rice husk was firstly treated with diafiltration and then by MBR to obtain and purify low molecular weight arabino-xylooligosaccharides (AXOS). Also in this study the various MBR configurations were studied. The best configuration in terms of productivity (93.3\% recovery yield vs $75.8 \%$ ) was the one in which the catalysis was carried out simultaneously with the separation process.

\subsection{Pectinase and $M B R$ in biorefineries}

Pectin is a complex polymer of carbohydrates present in the cell wall of the main higher plants. In recent years, pectic biomass is considered as an important source of feedstock, because it contains a low lignin concentration and in some industrial process (e.g. juice filtration) is considered a waste material, which can be valorized through hydrolysis process. It can be also used as starting source to produce galacturonic acid, which is a raw material in food, pharmacentical and cosmetic industry, due to its important properties or for pectin-derived oligosaccharides (POS). POS are an emerging class of prebiotic, but they can also have important therapeutic properties such as: ability to induce apoptosis in human colon cancer cells, anti-inflammatory and antiobesity properties, etc (Gómez et al., 2016). On the basis of the different pectic biomass used, oligosaccharides with different structure can be obtained such as arabinogalacto-oligosaccharides, arabinoxylooligosaccharides, galacto-oligosaccharides etc. Pectin hydrolysis can be carried out by both chemical and enzymatic methods, but as frequently observed the enzymatic methodology offers several advantages such as reaction in mild conditions avoiding corrosion, selective hydrolysis and higher reaction yield. However the pectic enzynes generally suffer from product inhibition of the monomer (galaturonic acid). For this reason, a separation process after hydrolysis is highly desired. This is the reason why membrane processes are generally coupled with enzynatic hydrolysis for pectin in MBR systems, which permit the continuous POS production, enzyme re-use and conversion increase due to inhibition product removal (Gónez et al., 2016). MBR technology for pectin hydrolysis is currently used by both inmobilized and non-immobilized enzyme, although the most used configuration is with free enzyme recirculated in the retantate side (Table 3) (Alkorta et al., 1995; Bélafi-Bakó et al., 2007; Rodriguez-Nogales et al., 2008; Rodríguez-Nogales et al., 2005). In the last mentioned systems, both flatsheet and hollow fiber membranes made of different materials were used. Two kind of reactors are used: sequential batch reactor and filtration (discontinuous) or simultaneous batch filtration process (continuous). In the first case, the reaction occurs in a first step after a certain incubation time without product separation. The membrane process is used in a second step to carry out the purification. To avoid the excessive production of monosaccharides, small amount of biocatalyst is used for this reason and the enzyme concentration to achieve the highest conversion is one of the most studied parameters (Mountzouris et al., 2002; Torras et al., 2008). The incubation time is another parameter frequently studied to control the MW of the products, but the nonspecific enzyme cleavage does not permit to control it. As a result, batch reactors coupled with membrane processes are not suitable for further application for the production of POS, since the final product have a wide MW distribution (Moure et al., 2006). Strategies for final products separation are based on the use of different membrane separation steps to obtain the different fractions of the product. Córdova et al. (2017) used three different steps of nanofiltration for oligosaccharides purification after hydrolysis in order to obtain products of target properties grouped in the desired MW range.

Nevertheless, important viscosity reduction of pectin solution in the MBR with free enzyme also without further purification by membrane processes is achieved, which is very useful in systems in which a viscous solution must be treated (e.g. filtration of fruit juice or olive mill waste water) and pectin causes membrane fouling (Gebreyohannes et al., 2013). In the work carried out by Baldassarre et al. (2018), a discontinuous (used as pre-treatment) and a continuous membrane reactor with free enzyne were used. This permitted to increase the volumetric productivity up to five times, demonstrating a real advantage respect to the traditional batch reactor. In the continuous MBR the process was intensified, but the flow through the membrane was lower than discontinuous systems, since large molecules tend to deposit on the menbrane surface enhancing transmembrane resistance. Nabarlatz et al. (2007) demonstrated that a high solute flux during oligosaccarides fractionation caused an increase of concentration polarization and an increased retention of low MW compounds. In particular a membrane selectivity decrease (a broader range of oligosaccharides passed through the membrane) of about $25 \%$ was observed when the flux was increased from 5 to $55 \mathrm{~L} \mathrm{~m}^{-2} \mathrm{~h}^{-1}$.

Enzyne immobilization on membranes for POS production overcomes a lot of problems related to both enzyme re-use and stability, targeted production of tailored products, fast POS removal and hence liniting monomer production. Nevertheless, few studies are currently applied for pectin hydrolysis in which BMRs are used. This can be due to additional problems due to enzyne inmobilization (steric hindrance, enzyme aggregation) and/or enzyme deactivation due to chenical cleaning and disinfection of the biocatalytic membrane. Gebreyohannes et al. (2016) demonstrated that inmobilizing the pectinase on magnetic nanoparticles, subsequently dispersed on the membrane surface by a magnetic field, permitted removal of the enzyme when necessary (e.g. 
Table 3

Use of MBR in pectin hydrolysis.

\begin{tabular}{|c|c|c|c|c|c|c|}
\hline Pectin source & Enzyme & $\begin{array}{l}\text { Enzyme } \\
\text { status }\end{array}$ & Product/work aim & $\begin{array}{l}\text { Membrane cut-off } \\
(\mathrm{kDa}) / \text { pore size }(\mu \mathrm{m})\end{array}$ & $\begin{array}{l}\text { Membrane } \\
\text { material }\end{array}$ & Reference \\
\hline Apple pomace & Endopectidase, polygalacturonase & $\mathrm{F}$ & fouling control & 10 & PS & $\begin{array}{l}\text { (Rodriguez-Nogales } \\
\text { et al., 2008) }\end{array}$ \\
\hline $\begin{array}{l}\text { Sugar beet, black } \\
\text { currant, red } \\
\text { currant }\end{array}$ & $\begin{array}{l}\text { Polygalacturonase from Aspergillus } \\
\text { niger }\end{array}$ & F & galacturonic acid/ & $45 /$ & PES & (Kiss et al., 2009) \\
\hline Commercial pectin & $\begin{array}{l}\text { Polygalacturonase from Aspergillus } \\
\text { niger }\end{array}$ & F & $\begin{array}{l}\text { galacturonic acid/study } \\
\text { of enzyme inhibition }\end{array}$ & $30 /$ & $\mathrm{RC}$ & $\begin{array}{l}\text { (Bélafi-Bakó et al., } \\
\text { 2007) }\end{array}$ \\
\hline Onion skin & Viscozyme (mixture of enzymes) & F & POS/ & $10 /$ & PS & $\begin{array}{l}\text { (Baldassarre et al., } \\
\text { 2018) }\end{array}$ \\
\hline Lemon peels & $\begin{array}{l}\text { Pectinex Ultra SP-L, pectinases from } \\
\text { Aspergillus aculeatus and Pectinase } 62 \mathrm{~L}\end{array}$ & F & POS/ & $1 /$ & $\mathrm{RC}$ & (Gómez et al., 2016) \\
\hline Sugar beet & Viscozyme L, & F & POS/ & $10 /$ & PS & (Elst et al., 2018) \\
\hline Citrus pectin & Polygalacturonase from A.niger & IMM & POS/ & $/ 0.05-0.1$ & titania & $\begin{array}{l}\text { (Szaniawski \& } \\
\text { Spencer, 1996) }\end{array}$ \\
\hline $\begin{array}{l}\text { Olive mill waste } \\
\text { water }\end{array}$ & pectinex 3XL & IMM & /pectin hydrolysis & $/ 0.4$ & $\mathrm{PE}$ & $\begin{array}{l}\text { (Gebreyohannes } \\
\text { et al., 2013) }\end{array}$ \\
\hline Citrus fruit pectin & polygalacturonase & IMM & /membrane fouling & $/ 0.1$ & PVDF & $\begin{array}{l}\text { (Gebreyohannes } \\
\text { et al., 2016) }\end{array}$ \\
\hline
\end{tabular}

PS: polysulphone, PES: polyethersulphone, RC: regenerated cellulose, PE: polyethylene, PVDF: polyvinylidene fluoride, IMM: inmobilized, F: free

membrane washing) and to distribute it avoiding steric hindrance improving enzyme kinetic performance. The use of biofunctionalized particles coupled with membrane process is widely employed now (Donato et al., 2012; Vitola et al., 2017, 2019), since it permits to recover the catalyst at the end of the process, the possibility to clean the membrane with solvent without deactivating the enzyme and to keep unaltered the chemical-physical and morphological structure of the membrane, generally modified during chemical biofunctionalization.

\subsection{Lipase and MBR in biorefineries}

Membrane processes and in particular MBR are innovative systems for biodiesel production and can be used both in esterification, transesterification and biodiesel refining. The involvement of lipase in biorefineries is mainly in transesterification of tryalcylgricerides to produce fatty acid (m)ethyl esters (FA(M)EE). The enzymatic esterification process generally involves the presence of the lipase (free or immobilized) extracted from different microorganisms (Pseudomonas fluorescens, Rhizopus Oryzae, Candida rugosa and Pseudomonas cepacia etc.), an alcohol (ethanol or methanol) and a source of triglycerides, which could be vegetable oils, non-edible oils (e.g. Jatropha), waste cooking oil or animal greases, microalgal oil etc (Badenes et al., 2013). Compared to the chemical process, biological esterification is highly advantageous, since it promotes high conversion in mild operative conditions. Besides, in the enzymatic transesterification, no soaps are produced, which imply the absence of further washing steps, with the reduction of production costs and wastewater. The innovation of MBR in the enzymatic esterification processes is also due to the process intensification (reaction and separation in a single unit) which also significantly reduce the production steps and the system compactness with respect to the traditional methods. However, the enzyme cost is considered as one of the main limitation of MBR in general, which could be reduced by the enzyme inmobilization (Fjerbaek et al., 2009), because it significantly increases enzyme stability and re-use. This is in fact the trend observed in recent literature related to MBR and transesterification process (Table 4); where the enzyme is almost always immobilized within polymeric membranes (mainly by covalent attachment).

Another important problem to overcome in MBR is the enzyme

Table 4

MBR systens for bioediesel production.

\begin{tabular}{|c|c|c|c|c|c|c|c|c|}
\hline Enzyme & $\begin{array}{l}\text { Enzyme status } \\
\text { /Immobilization }\end{array}$ & Membrane & $\begin{array}{l}\text { Membrane }(k D a) / \\
\text { pore size }(\mu \mathrm{m})\end{array}$ & TAG source & Alcohol & $\begin{array}{l}\text { Conversion } \\
(\%)\end{array}$ & $\begin{array}{l}\text { Stability } \\
\text { (days) }\end{array}$ & Ref. \\
\hline $\begin{array}{l}\text { Lipase from Candida } \\
\text { sp.99-125 }\end{array}$ & IMM/adsorption & textile & - & $\begin{array}{l}\text { salad oil and } \\
\text { waste oil }\end{array}$ & $\begin{array}{l}\mathrm{MeOH} \text { in } \mathrm{n}- \\
\text { hexane }\end{array}$ & 96 & $\begin{array}{l}\text { more than } \\
20\end{array}$ & (Nie et al., 2006) \\
\hline $\begin{array}{l}\text { Lipase from Candida } \\
\text { sp.99-125 }\end{array}$ & IMM/covalent & textile & - & lard & $\mathrm{MeOH}$ & 85 & 7.5 & (Lu et al., 2007) \\
\hline $\begin{array}{l}\text { Lipase from } \\
\quad P . \text { fluorescens }\end{array}$ & IMM/adsorption & PES & $300 /$ & triolein & $\mathrm{MeOH}$ & 80 & 12 & $\begin{array}{l}\text { (Machsun et al., } \\
\text { 2010) }\end{array}$ \\
\hline $\begin{array}{l}\text { Lipase from } \\
\quad P . \text { fluorescens }\end{array}$ & IMM/covalent & PVDF & $/ 0.45$ & soybean oil & $\begin{array}{l}\mathrm{MeOH} \text { in } \mathrm{n}- \\
\text { hexane }\end{array}$ & 95 & 7 & (Kuo et al., 2013) \\
\hline Lipase from $P$. cepacea & IMM/covalent & PAN & - & soybean oil & $\mathrm{MeOH}$ & 90 & 10 & (Li et al., 2019) \\
\hline $\begin{array}{l}\text { Lipase B form } \\
\text { C. antarctica l (CalB) }\end{array}$ & IMM/covalent & $\mathrm{RC}$ & $10,25,50 /$ & soybean oil & $\mathrm{MeOH}$ & 97.5 & - & (Ko et al., 2012b) \\
\hline $\begin{array}{l}\text { Lipase from C. rugosa } \\
\text { (Amano AY-30) }\end{array}$ & IMM/covalent & PVDF & $/ 0.45$ & soybean oil & $\mathrm{MeOH}$ & 97 and 95 , & 7 & (Kuo et al., 2013) \\
\hline $\begin{array}{l}\text { Lipase from Mucor } \\
\text { miehei }\end{array}$ & IMM/covalent & PES & $/ 0.65$ & $\begin{array}{l}\text { sunflower } \\
\text { seeds oil }\end{array}$ & $\mathrm{Bu}-\mathrm{OH}$ & 100 & $\begin{array}{l}\text { missing } \\
\text { data }\end{array}$ & $\begin{array}{l}\text { (Handayani } \\
\text { et al., 2016) }\end{array}$ \\
\hline Lipase from C.rugosa & $\mathrm{F} /-$ & PAN & $100 /$ & $\begin{array}{l}\text { Eruca sativa } \\
\text { oil. }\end{array}$ & $\mathrm{MeOH}$ & 100 & 3 & $\begin{array}{l}\text { (Aghababaie } \\
\text { et al., 2019) }\end{array}$ \\
\hline $\begin{array}{l}\text { Lipase B from } \\
\text { C. antarctica }\end{array}$ & IMM/covalent & PAN & - & soybean oil & $\mathrm{MeOH}$ & 80 & 12.5 & (Li et al., 2019) \\
\hline $\begin{array}{l}\text { Lipase from } \\
\text { T. lanuginosus }\end{array}$ & $\mathrm{F} /-$ & PAN & $/ 0.2$ & Sunflower oil & $\mathrm{MeOH}$ & - & - & $\begin{array}{l}\text { (Sokač et al. } \\
2020\end{array}$ \\
\hline Lipase & IMM & PES & $/ 0.001$ & Karanja oil & $\mathrm{EtOH}$ & 88 & - & (Kumar 2021 \\
\hline
\end{tabular}

PES: polyethersulphone: PVDF: polyvinylidene fluoride, PAN: polyacrylonitrile, RC: regenerated cellulose, IMM: inmmobilized, F: free, MeOH: nethanol 
deactivation due to the interaction with methanol or ethanol. In particular, a molar ratio of methanol/oil higher than $1 / 2$ causes irreversible enzyme denaturation (Su et al., 2015)(Su et al., 2020). Besides, the glycerol produced during the transesterification process, being more soluble in water, limits the interaction of the enzyme with the substrate, forming a film around the enzyme. This film does not pernit the interaction with the hydrophobic substrate, with a consecutive conversion decrease. To overcome this process, different strategies were proposed, such as continuous addition of methanol, several methods for methanol supply (in oil or in water), selective removal or glycerol etc.

(Belafi-Bako et al., 2002). Within the different strategies, the use of two-phase separated membrane reactors, widely applied in MBR with lipase, seems one of the most promising (Aghababaie et al., 2019). In the work carried out by Ko et al. (2012a), a two-phase MBR permitted a stepwise addition of methanol and a selective removal of glycerol, thanks to a regenerated UF membrane, coupled with a stirred tank reactor (STR). In this case, the membrane role was to supply and remove methanol and glycerol respectively, but it also worked as a contactor between the hydrophilic and hydrophobic phase (Fig. 4a). In the two-phase MBR developed by Aghababaie et al. (2019)(Fig. 4b) an additional role of the membrane is to retain the biocatalyst, which is in the oil phase. In both systems it was possible to reach a high conversion degree and stability.

\section{Challenges and future perspective on the use of MBR in biorefinery}

The main drawbacks which hindered the development of MBR in biorefinery industries are mainly the low enzyme stability and the membrane fouling. To address these issues, strategies also proposed in this review, must be taken into account, mainly related to the selection of membrane material, operative conditions optimization and reactor engineering design. In particular:

- the conjugation of biofunctionalized magnetic nanoparticle with membrane processes can introduce an innovative strategy to selectively remove the biocatalyst when fouling occurs. This will permit cyclic membrane cleaning with solvents or backflushig, which are generally damaging for the enzyme.

- The use of estremophiles enzyme, which can tolerate high temperature could alleviate cake-layer formation on the membrane, increasing the stability of the biocatalytic membrane.

- The introduction of integrated membrane processes associated with MBR or cascade enzymatic reactions in separated MBRs could be also interesting strategies to pre-treat the stream before the enzymatic reaction, permitting membrane foulig and enzyme reaction to be checked in separated steps.

- Another interesting approach is the possible use of microfiltration membranes with immobilized enzyme in a submerged configuration, which can ensure large volumetric productivity.

In order to fully apply the mentioned strategies in future applications, the integration between membrane science, genetic engineering, and chemical engineering is needed.

\section{Conclusions}

The use of MBRs in biorefineries for the first time was critically analyzed. Carbohydrate hydrolysis, biodiesel production, aglycones production, POS and galacturonic acid production and XOS production were described and critically reviewed.

In all the analysed sectors MBRs promote continuous reaction system, enzyme re-use and removal of inhibition products, while increasing the system efficiency. To promote the development of MBRs on a larger scale some drawbacks of this technology must be considered. Innovative strategies proposed in this review, can promote advances in membrane saving, membrane fouling control and enzyme stability inprovement.
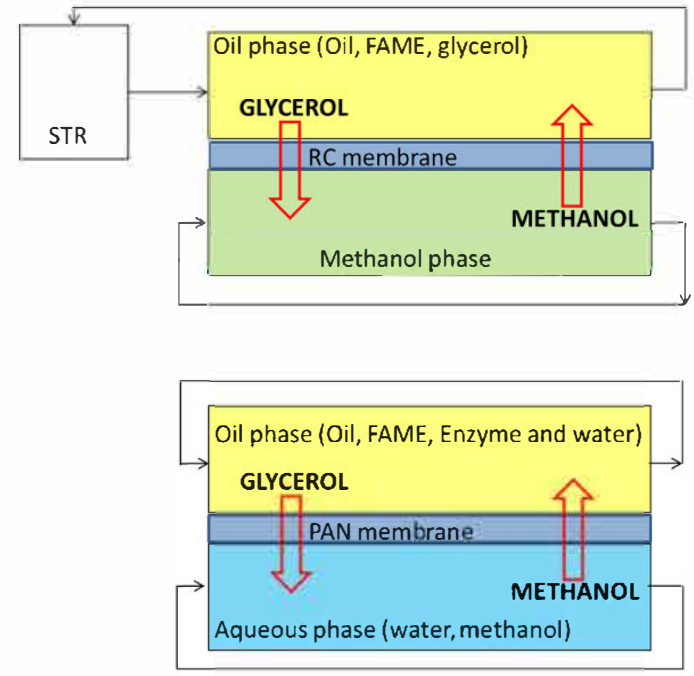

Fig. 4. Scheme of glycerol removal and methanol supply to two-phase MBR. A) system developed by Ko et al. (Ko et al., 2012b); B) systen developed by Aghababaie et al. (Aghababaie et al., 2019).

\section{Declaration of Competing Interest}

The authors declare that they have no known competing financial interests or personal relationships that could have appeared to influence the work reported in this paper.

\section{Acknowledgement}

The authors thank the International Exchanges 2019 Round 2 of The Royal Society, contract number IES $\backslash R 2 \backslash 192205$ for the financial support. This work was sponsored by King Abdullah University of Science and Technology (KAUST), grants REP/1/3988-06-01 and REP/1/398809-01.

\section{References}

Acosta-Fernández, R., Poerio, T., Nabarlatz, D., Giorno, L., Mazzei, R., 2020. Enzymatic Hydrolysis of Xylan from Coffee Parchment in Membrane Bioreactors. Industrial \& Engineering Chemistry Research 59 (16), 7346-7354.

Aghababaie, M., Beheshti, M., Razmjou, A., Bordbar, A.-K., 2019. Two phase enzymatic membrane reactor for the production of biodiesel from crude Eruca sativa oil. Renewable Energy 140, 104-110.

Aguilar, D.L., Rodríguez-Jasso, R.M., Zanuso, E., de Rodríguez, D.J., Amaya-Delgado, L., Sanchez, A., Ruiz, H.A., 2018. Scale-up and evaluation of hydrothermal pretreatment in isothermal and non-isothermal regimen for bioethanol production using agave bagasse. Bioresource technology 263, 112-119.

Ahamed, A., Vermette, P., 2008. Enhanced enzyme production from mixed cultures of Trichoderma reesei RUT-C30 and Aspergillus niger LMA grown as fed batch in a stirred tank bioreactor. Biochemical Engineering Journal 42 (1), 41-46.

Alkorta, I., Garbisu, C., Llama, M.J., Serra, J.L., 1995. Viscosity decrease of pectin and fruit juices catalyzed by pectin lyase from Penicillium italicum in batch and continuous-flow membrane reactors. Biotechnology techniques 9 (2), 95-100.

Andrić, P., Meyer, A.S., Jensen, P.A., Dam-Johansen, K., 2010a. Reactor design for minimizing product inhibition during enzymatic lignocellulose hydrolysis: I. Significance and mechanism of cellobiose and glucose inhibition on cellulolytic enzymes. Biotechnology Advances 28 (3), 308-324. https://doi.org/10.1016/j. biotechadv.2010.01.003.

Andrić, P., Meyer, A.S., Jensen, P.A., Dam-Johansen, K., 2010b. Reactor design for minimizing product inhibition during enzymatic lignocellulose hydrolysis: II. Quantification of inhibition and suitability of membrane reactors. Biotechnology Advances 28 (3), 407-425.

Badenes, S.M., Ferreira, F.C., Cabral, J.M., 2013. Membrane Bioreactors for Biofuel Production. Separation and Purification Technologies in Biorefineries 377-407.

Baldassarre, S., Babbar, N., Van Roy, S., Dejonghe, W., Maesen, M., Sforza, S., Elst, K., 2018. Continuous production of pectic oligosaccharides from onion skins with an enzyme membrane reactor. Food chemistry 267, 101-110.

Bélafi-Bakó, K., Eszterle, M., Kiss, K., Nemestóthy, N., Gubicza, L., 2007. Hydrolysis of pectin by Aspergillus niger polygalacturonase in a membrane bioreactor. Journal of Food Engineering 78 (2), 438-442. 
Bélafi-Bakó, K., Koutinas, A., Nemestóthy, N., Gubicza, L., Webb, C., 2006. Continuous enzymatic cellulose hydrolysis in a tubular membrane bioreactor. Enzyme and Microbial Technology 38 (1), 155-161.

Belafi-Bako, K., Kovacs, F., Gubicza, L., Hancsok, J., 2002. Enzymatic biodiesel production from sunflower oil by Candida antarctica lipase in a solvent-free system. Biocatalysis and Biotransformation 20 (6), 437-439.

Berlin, A., Maximenko, V., Gilkes, N., Saddler, J., 2007. Optimization of enzyme complexes for lignocellulose hydrolysis. Biotechnol Bioeng 97 (2), 287-296.

Cai, H., Han, J., Wang, M., Davis, R., Biddy, M., Tan, E., 2018. Life-cycle analysis of integrated biorefineries with co-production of biofuels and bio-based chemicals: coproduct handling methods and implications. Biofuels, Bioproducts and Biorefining $12(5), 815-833$.

Cantarella, M., Mucciante, C., Cantarella, L., 2014. Inactivating effects of lignin-derived compounds released during lignocellulosic biomass pretreatment on the endoglucanase catalyzed hydrolysis of carboxymethylcellulose: A study in continuous stirred ultrafiltration-membrane reactor. Bioresource Technology 156, 48-56. https://doi.org/10.1016/j. biortech.2013.12.124.

Chang, H.N., 2018. Introduction to Emerging Areas in Bioengineering. Emerging Areas in Bioengineering 1, 3-20.

Chang, H.N., Yoo, I.-K., Kim, B.S., 1994. High density cell culture by membrane-based cell recycle. Biotechnology advances 12 (3), 467-487.

Chang, K.-L., Thitikorn-amorn, J., Chen, S.-H., Hsieh, J.-F., Ratanakhanokchai, K., Huang, P.-J., Lin, T.-C., Chen, S.-T., 2011. Improving the remaining activity of lignocellulolytic enzymes by membrane entrapment. Bioresource Technology 102 (2), 519-523.

Chen, G., Song, W., Qi, B., Lu, J., Wan, Y., 2013. Recycling cellulase from enzymatic hydrolyzate of acid treated wheat straw by electroultrafiltration. Bioresource Technology 144, 186-193.

Chon, K., KyongShon, H.o., Cho, J., 2012. Membrane bioreactor and nanofiltration hybrid system for reclamation of municipal wastewater: Removal of nutrients, organic matter and micropollutants. Bioresource Technology 122, 181-188. https:// doi.org/10.1016/j.biortech.2012.04.048.

Choudhury, B., Swaminathan, T., 2006. Lactic acid fermentation in cell-recycle membrane bioreactor. Applied Biochemistry and Biotechnology 128 (2), 171-183.

Conidi, C., Mazzei, R., Cassano, A., Giorno, L., 2014. Integrated membrane system for the production of phytotherapics from olive mill wastewaters. Journal of Membrane Science 454, 322-329.

Córdova, A., Astudillo, C., Santibañez, L., Cassano, A., Ruby-Figueroa, R., Illanes, A., 2017. Purification of galacto-oligosaccharides (GOS) by three-stage serial nanofiltration units under critical transmembrane pressure conditions. Chemical Engineering Research and Design 117, 488-499.

Dizge, N., Epsztein, R., Cheng, W., Porter, C.J., Elimelech, M., 2018. Biocatalytic and salt selective multilayer polyelectrolyte nanofiltration membrane. Journal of Membrane Science 549, 357-365.

Donato, L., Algieri, C., Miriello, V., Mazzei, R., Clarizia, G., Giorno, L., 2012. Biocatalytic zeolite membrane for the production of L-DOPA. Journal of membrane science 407, 86-92.

Drioli, E., Giorno, L., 2020. Biocatalytic membrane reactors: applications in biotechnology and the pharmaceutical industry. CRC Press.

Drioli, E., Giorno, L., 2009. Membrane operations: innovative separations and transformations. John Wiley \& Sons.

Elst, K., Babbar, N., Van Roy, S., Baldassarre, S., Dejonghe, W., Maesen, M., Sforza, S. 2018. Continuous production of pectic oligosaccharides from sugar beet pulp in a cross flow continuous enzyme membrane reactor. Bioprocess and biosystems engineering 41 (11), 1717-1729.

Enamala, M.K., Enamala, S., Chavali, M., Donepudi, J., Yadavalli, R., Kolapalli, B., Aradhyula, T.V., Velpuri, J., Kuppam, C., 2018. Production of biofuels from microalgae-A review on cultivation, harvesting, lipid extraction, and numerous applications of microalgae. Renewable and Sustainable Energy Reviews 94, 49-68.

Fan, S., Xiao, Z., Li, M., Li, S., 2016. Pervaporation membrane bioreactor with permeate fractional condensation and mechanical vapor compression for energy efficient ethanol production. Applied Energy 179, 939-947.

Fjerbaek, L., Christensen, K.V., Norddahl, B., 2009. A review of the current state of biodiesel production using enzymatic transesterification. Biotechnology and bioengineering 102 (5), 1298-1315.

Gavlighi, H.A., Meyer, A.S., Mikkelsen, J.D., 2013. Enhanced enzymatic cellulose degradation by cellobiohydrolases via product removal. Biotechnology letters 35 (2), 205-212.

Gebreyohannes, A.Y., Bilad, M.R., Verbiest, T., Courtin, C.M., Dornez, E., Giomo, L., Curcio, E., Vankelecom, I.F.J., 2015. Nanoscale tuning of enzyme localization for enhanced reactor performance in a novel magnetic-responsive biocatalytic membrane reactor. Journal of Membrane Science 487, 209-220.

Gebreyohannes, A.Y., Dharmjeet, M., Swusten, T., Mertens, M., Verspreet, J., Verbiest, T., Courtin, C.M., Vankelecom, I.F.J., 2018. Simultaneous glucose production from cellulose and fouling reduction using a magnetic responsive membrane reactor with superparamagnetic nanoparticles carrying cellulolytic enzymes. Bioresource Technology 263, 532-540. https://doi.org/10.1016/j. biortech.2018.05.002

Gebreyohannes, A.Y., Giorno, L., 2015. Nanotechnology Membrane. In: Drioli, E., Giorno, L. (Eds.), Encyclopedia of Membranes. Springer, Berlin Heidelberg. Berlin, Heidelberg, pp. 1-5.

Gebreyohannes, A.Y., Giorno, L., Vankelecom, I.F.J., Verbiest, T., Aimar, P., 2017. Effect of operational parameters on the performance of a magnetic responsive biocatalytic membrane reactor. Chemical Engineering Journal 308, 853-862.

Gebreyohannes, A.Y., Mazzei, R., Curcio, E., Poerio, T., Drioli, E., Giorno, L., 2013. Study on the in Situ Enzymatic Self Cleansing of Microfiltration Membrane for Valorization of Olive Mill Wastewater. Industrial \& Engineering Chemistry Research 52 (31), 10396-10405.

Gebreyohannes, A.Y., Mazzei, R., Poerio, T., Aimar, P., Vankelecom, I.F.J., Giorno, L., 2016. Pectinases immobilization on magnetic nanoparticles and their anti-fouling performance in a biocatalytic membrane reactor. RSC Advances 6 (101), 98737-98747.

Giorno, L., Chojnacka, K., Donato, L., Drioli, E., 2002. Study of a Cell-Recycle Membrane Fermentor for the Production of Lactic Acid by Lactobacillus b ulgaricus. Industrial \& engineering chemistry research 41 (3), 433-440.

Giorno, L., D'amore, E., Mazzei, R., Piacentini, E., Zhang, J., Drioli, E., Cassano, R., Picci, N. 2007. An innovative approach to improve the performance of a two separate phase enzyme membrane reactor by immobilizing lipase in presence of emulsion. Journal of membrane science, 295(1-2), 95-101.

Giorno, L., Drioli, E., 2000. Biocatalytic membrane reactors: applications and perspectives. Trends in biotechnology 18 (8), 339-349.

Giorno, L., Drioli, E., 2009. Membrane Operations: Innovative Separations and Transformations. Wiley-VCH Verlag \& Company KGaA.

Giorno, L., Mazzei, R., Drioli, E., 2009. Biochemical membrane reactors in industrial processes. Innovative Separations and Transformations, Membrane Operations, pp. 397-409.

Giorno, L., Zhang, J., Drioli, E., 2006. Study of mass transfer performance of naproxen acid and ester through a multiphase enzyme-loaded membrane system. Journal of membrane science 276 (1-2), 59-67.

Giorno, L., Mazzei, R., Piacentini, E., Drioli, E. 2017. Food Applications of Membrane Bioreactors. in: Engineering Aspects of Membrane Separation and Application in Food Processing, (Ed.) E.B.-M. Robert W. Field, Frank Lipnizki, Gyula Vatai CRC Press Taylor \& Francis Group, pp. 299-360.

Goh, S., Zhang, J., Liu, Y., Fane, A.G., 2015. Membrane Distillation Bioreactor (MDBR)-A lower Green-House-Gas (GHG) option for industrial wastewater reclamation. Chemosphere 140, 129-142.

Gómez, B., Yáñez, R., Parajó, J.C., Alonso, J.L., 2016. Production of pectin-derived oligosaccharides from lemon peels by extraction, enzymatic hydrolysis and membrane filtration. Journal of Chemical Technology \& Biotechnology 91 (1), 234-247.

González-Muñoz, M.J., Domínguez, H., Parajó, J.C., 2008. Depolymerization of xylanderived products in an enzymatic membrane reactor. Journal of Membrane Science $320(1-2), 224-231$

Guo, H., Chang, Y., Lee, D.-J., 2018. Enzymatic saccharification of lignocellulosic biorefinery: research focuses. Bioresource technology 252, 198-215.

Handayani, N., Wahyuningrum, D., Zulfikar, M.A., Nurbaiti, S., Radiman, C.L., Buchari. 2016. The synthesis of biodiesel catalyzed by Mucor miehei lipase immobilized onto aminated polyethersulfone membranes. Bioresources and Bioprocessing, 3(1), 22.

Holloway, R.W., Achilli, A., Cath, T.Y., 2015. The osmotic membrane bioreactor: a critical review. Environmental Science: Water Research \& Technology 1 (5), $581-605$.

Kiss, K., Nemestóthy, N., Gubicza, L., Bélafi-Bakó, K., 2009. Vacuum assisted membrane bioreactor for enzymatic hydrolysis of pectin from various agro-wastes. Desalination 241 (1-3), 29-33.

Ko, M.J., Park, H.J., Hong, S.Y., Yoo, Y.J., 2012a. Continuous biodiesel production using in situ glycerol separation by membrane bioreactor system. Bioprocess and biosystems engineering 35 (1-2), 69-75.

Ko, M.J., Park, H.J., Hong, S.Y., Yoo, Y.J., 2012b. Continuous biodiesel production using in situ glycerol separation by membrane bioreactor system. Bioprocess and Biosystems Engineering 35 (1), 69-75.

Kuo, C.-H., Peng, L.-T., Kan, S.-C., Liu, Y.-C., Shieh, C.-J., 2013. Lipase-immobilized biocatalytic membranes for biodiesel production. Bioresource technology 145 , 229-232.

Ladole, M.R., Mevada, J.S., Pandit, A.B., 2017. Ultrasonic hyperactivation of cellulase immobilized on magnetic nanoparticles. Bioresource Technology 239 (Supplement C), 117-126.

Li, Y., Wang, H., Lu, J., Chu, A., Zhang, L., Ding, Z., Xu, S., Gu, Z., Shi, G., 2019. Preparation of immobilized lipase by modified polyacrylonitrile hollow membrane using nitrile-click chemistry. Bioresource technology 274, 9-17.

Lim, Shin Yuan, Ghazali, Nazlee Faisal, 2020. Product Removal Strategy and Fouling Mechanism for Cellulose Hydrolysis in Enzymatic Membrane Reactor. Waste Biomass Valor 11 (10), 5575-5590. https://doi.org/10.1007/s12649-020-01020-6.

Liu, J., Lu, J., Cui, Z., 2011. Enzymatic hydrolysis of cellulose in a membrane bioreactor: assessment of operating conditions. Bioprocess and biosystems engineering 34 (5), 525-532.

Lozano, P., Bernal, B., Jara, A.G., Belleville, M.-P., 2014. Enzymatic membrane reactor for full saccharification of ionic liquid-pretreated microcrystalline cellulose. Bioresource Technology 151, 159-165.

Lu, J., Nie, K., Xie, F., Wang, F., Tan, T., 2007. Enzymatic synthesis of fatty acid methyl esters from lard with immobilized Candida sp. 99-125. Process Biochemistry 42 (9), $1367-1370$.

Lupoi, J.S., Smith, E.A., 2011. Evaluation of nanoparticle-immobilized cellulase for improved ethanol yield in simultaneous saccharification and fermentation reactions. Biotechnol Bioeng 108 (12), 2835-2843.

Machsun, A.L., Gozan, M., Nasikin, M., Setyahadi, S., Yoo, Y.J., 2010. Membrane microreactor in biocatalytic transesterification of triolein for biodiesel production. Biotechnology and Bioprocess Engineering 15 (6), 911-916.

Mahboubi, A., Uwineza, C., Doyen, W., De Wever, H., Taherzadeh, M.J., 2020. Intensification of lignocellulosic bioethanol production process using continuous double-staged immersed membrane bioreactors. Bioresource technology 296, 122314. 
Mahboubi, Amir, Ylitervo, Päivi, Doyen, Wim, De Wever, Heleen, Molenberghs, Bart, Taherzadeh, Mohammad J., 2017a. Continuous bioethanol fermentation from wheat straw hydrolysate with high suspended solid content using an immersed flat sheet membrane bioreactor. Bioresource Technology 241, 296-308. https://doi.org/ 10.1016/j.biortech.2017.05.125.

Mahboubi, A., Ylitervo, P., Doyen, W., De Wever, H., Molenberghs, B., Taherzadeh, M.J., 2017b. Continuous bioethanol fermentation from wheat straw hydrolysate with high suspended solid content using an immersed flat sheet membrane bioreactor. Bioresource Technology 241 (Supplement C), 296-308.

Malmali, M., Stickel, J., Wickramasinghe, S.R., 2015. Investigation of a submerged membrane reactor for continuous biomass hydrolysis. Food and Bioproducts Processing 96, 189-197.

Mazzei, R., Drioli, E., Giorno, L., 2010. Biocatalytic membrane reactor and membrane emulsification concepts combined in a single unit to assist production and separation of water unstable reaction products. Journal of Membrane Science 352 (1-2), $166-172$.

Mazzei, R., Drioli, E., Giorno, L., 2012. Enzyme membrane reactor with heterogenized $\beta$-glucosidase to obtain phytotherapic compound: Optimization study. Journal of Membrane Science 390-391, 121-129.

Mazzei, R., Emma, P., Abaynesh Yihdego, G., Lidietta, G., 2017a. Membrane Bioreactors in Food, Pharmaceutical and Biofuel Applications: State of the Art. Progresses and Perspectives. Current Organic Chemistry 21 (17), 1671-1701.

Mazzei, R., Giorno, L., Piacentini, E., Mazzuca, S., Drioli, E., 2009. Kinetic study of a biocatalytic membrane reactor containing immobilized $\beta$-glucosidase for the hydrolysis of oleuropein. Journal of Membrane Science 339 (1-2), 215-223.

Mazzei, R., Piacentini, E., Drioli, E., Giorno, L., 2013. Membrane bioreactors for green processing in a sustainable production system. Process intensification for green chemistry: engineering solutions for sustainable chemical processing 227-250.

Mazzei, R., Piacentini, E., Nardi, M., Poerio, T., Bazzarelli, F., Procopio, A., Di Gioia, M. L., Rizza, P., Ceraldi, R., Morelli, C., Giorno, L., Pellegrino, M., 2020. Production of Plant-Derived Oleuropein Aglycone by a Combined Membrane Process and Evaluation of Its Breast Anticancer Properties. in: Frontiers in bioengineering and biotechnology Vol. 8, 908.

Mazzei, R., Piacentini, E., Yihdego Gebreyohannes, A., Giorno, L., 2017b. Membrane bioreactors in food, pharmaceutical and biofuel applications: state of the art, progresses and perspectives. Current Organic Chemistry 21 (17), 1671-1701.

Mountzouris, K., Gilmour, S., Rastall, R., 2002. Continuous production of oligodextrans via controlled hydrolysis of dextran in an enzyme membrane reactor. Journal of Food Science 67 (5), 1767-1771.

Moure, A., Gullón, P., Domínguez, H., Parajó, J.C., 2006. Advances in the manufacture, purification and applications of xylo-oligosaccharides as food additives and nutraceuticals. Process Biochemistry 41 (9), 1913-1923.

Nabarlatz, D., Torras, C., Garcia-Valls, R., Montané, D., 2007. Purification of xylo oligosaccharides from almond shells by ultrafiltration. Separation and Purification Technology 53 (3), 235-243.

Nguyen, L.T., Neo, K.R.S., Yang, K.-L., 2015. Continuous hydrolysis of carboxymethyl cellulose with cellulase aggregates trapped inside membranes. Enzyme and Microbial Technology 78, 34-39.

Nguyenhuynh, T., Nithyanandam, R., Chong, C.H., Krishnaiah, D., 2017. Configuration modification of a submerged membrane reactor for enzymatic hydrolysis of cellulose. Biocatalysis and Agricultural Biotechnology 12, 50-58.

Nie, K., Xie, F., Wang, F., Tan, T., 2006. Lipase catalyzed methanolysis to produce biodiesel: optimization of the biodiesel production. Journal of Molecular Catalysis B: Enzymatic $43(1-4), 142-147$.

Piacentini, E., Mazzei, R., Bazzarelli, F., Ranieri, G., Poerio, T., Giorno, L., 2019. Oleuropein Aglycone Production and Formulation by Integrated Membrane Process. Industrial \& Engineering Chemistry Research 58 (36), 16813-16822.

Piacentini, E., Mazzei, R., Giorno, L., 2021. Comparison between Lipase Performance Distributed at the $\mathrm{O} / \mathrm{W}$ Interface by Membrane Emulsification and by Mechanical Stirring. Membranes 11 (2), 137.

Pinelo, M., Jonsson, G., Meyer, A.S., 2009. Membrane technology for purification of enzymatically produced oligosaccharides: molecular and operational features affecting performance. Separation and Purification Technology 70 (1), 1-11.

Qi, B., Luo, J., Chen, G., Chen, X., Wan, Y., 2012. Application of ultrafiltration and nanofiltration for recycling cellulase and concentrating glucose from enzymatic hydrolyzate of steam exploded wheat straw. Bioresource Technology 104, 466-472.

Ranieri, G., Mazzei, R., Poerio, T., Bazzarelli, F., Wu, Z., Li, K., Giorno, L., 2018. Biorefinery of olive leaves to produce dry oleuropein aglycone: Use of homemade ceramic capillary biocatalytic membranes in a multiphase system. Chemical Engineering Science 185, 149-156.
Roche, C.M., Dibble, C.J., Knutsen, J.S., Stickel, J.J., Liberatore, M.W., 2009. Particle concentration and yield stress of biomass slurries during enzymatic hydrolysis at high-solids loadings. Biotechnology and bioengineering 104 (2), 290-300.

Rodrigues, É.F., Ficanha, A.M.M., Dallago, R.M., Treichel, H., Reinehr, C.O., Machado, T P., Nunes, G.B., Colla, L.M., 2017. Production and purification of amylolytic enzymes for saccharification of microalgal biomass. Bioresource Technology 225 (Supplement C), 134-141.

Rodriguez-Nogales, J.M., Ortega, N., Perez-Mateos, M., Busto, M.D., 2008. Pectin hydrolysis in a free enzyme membrane reactor: An approach to the wine and juice clarification. Food chemistry 107 (1), 112-119.

Rodríguez-Nogales, J.M., Ortega, N., Perez-Mateos, M., Busto, M.D., 2005. Operational Stability and Kinetic Study of a Membrane Reactor with Pectinases from Aspergillus niger. Journal of Food Science 70 (2), E104-E108.

Rosgaard, L., Pedersen, S., Cherry, J.R., Harris, P., Meyer, A.S., 2006. Efficiency of new fungal cellulase systems in boosting enzymatic degradation of barley straw lignocellulose. Biotechnol Prog 22 (2), 493-498.

Sakaki, K., Giorno, L., Drioli, E., 2001. Lipase-catalyzed optical resolution of racemic naproxen in biphasic enzyme membrane reactors. Journal of Membrane Science 184 (1), 27-38.

Singh, A., Jasso, R.M.R., Gonzalez-Gloria, K.D., Rosales, M., Cerda, R.B., Aguilar, C.N., Singhania, R.R., Ruiz, H.A., 2019. The enzyme biorefinery platform for advanced biofuels production. Bioresource Technology Reports 7, 100257.

Song, H., Liu, J., 2019. Forward osmosis membrane bioreactor using Bacillus and membrane distillation hybrid system for treating dairy wastewater. Environmental technology $1-12$

Song, Q., Mao, Y., Wilkins, M., Segato, F., Prade, R. 2016a. Cellulase immobilization on superparamagnetic nanoparticles for reuse in cellulosic biomass conversion.

Stickel, J.J., Knutsen, J.S., Liberatore, M.W., Luu, W., Bousfield, D.W., Klingenberg, D.J., Scott, C.T., Root, T.W., Ehrhardt, M.R., Monz, T.O., 2009. Rheology measurements of a biomass slurry: an inter-laboratory study. Rheologica Acta 48 (9), 1005-1015.

Su, F., Li, G.-L., Fan, Y.-L., Yan, Y.-J., 2015. Enhancing biodiesel production via a synergic effect between immobilized Rhizopus oryzae lipase and Novozym 435. Fuel Processing Technology 137, 298-304.

Su, Z., Luo, J., Li, X., Pinelo, M., 2020. Enzyme membrane reactors for production of oligosaccharides: A review on the interdependence between enzyme reaction and membrane separation. Separation and Purification Technology, p. 116840.

Sueb, M.S.M., Luo, J., Meyer, A.S., Jørgensen, H., Pinelo, M., 2017. Impact of the fouling mechanism on enzymatic depolymerization of xylan in different configurations of membrane reactors. Separation and Purification Technology 178, 154-162.

Suurnäkki, A., Tenkanen, M., Siika-aho, M., Niku-Paavola, M.-L., Viikari, L., Buchert, J., 2000. Trichoderma reesei cellulases and their core domains in the hydrolysis and modification of chemical pulp. Cellulose 7 (2), 189-209.

Szaniawski, A.R., Spencer, H.G., 1996. Effects of Pectin Concentration and Crossflow Velocity on Permeability in the Microfiltration of Dilute Pectin Solutions by Macroporous Titania Membranes Containing Immobilized Pectinase. Biotechnol. Prog. 12 (3), 403-405. https://doi.org/10.1021/bp9500829.

Tay, Ming Feng, Liu, Chang, Cornelissen, Emile R., Wu, Bing, Chong, Tzyy Haur, 2018. The feasibility of nanofiltration membrane bioreactor (NF-MBR)+reverse osmosis (RO) process for water reclamation: Comparison with ultrafiltration membrane bioreactor (UF-MBR)+RO process. Water Research 129, 180-189. https://doi.org/ 10.1016/j.watres.2017.11.013.

Tian, S.-Q., Wang, X.-W., Zhao, R.-Y., Ma, S. 2015. Recycling Cellulase from Enzymatic Hydrolyzate of Laser-Pretreated Corn Stover by UF Membrane.

Torras, C., Nabarlatz, D., Vallot, G., Montané, D., Garcia-Valls, R., 2008. Composite polymeric membranes for process intensification: Enzymatic hydrolysis of oligodextrans. Chemical Engineering Journal 144 (2), 259-266.

Vitola, Giuseppe, Büning, Dominic, Schumacher, Jens, Mazzei, Rosalinda, Giorno, Lidietta, Ulbricht, Mathias, 2017. Development of a Novel Immobilization Method by Using Microgels to Keep Enzyme in Hydrated Microenvironment in Porous Hydrophobic Membranes. Macromol. Biosci. 17 (5), 1600381. https://doi org/10.1002/mabi.201600381.

Vitola, G., Mazzei, R., Poerio, T., Barbieri, G., Fontananova, E., Büning, D., Ulbricht, M., Giorno, L., 2019. Influence of Lipase Immobilization Mode on Ethyl Acetate Hydrolysis in a Continuous Solid-Gas Biocatalytic Membrane Reactor. Bioconjugate Chemistry 30 (8), 2238-2246.

Ximenes, E., Kim, Y., Mosier, N., Dien, B., Ladisch, M., 2011. Deactivation of cellulases by phenols. Enzyme Microb Technol 48 (1), 54-60.

Xu, J., Huo, S., Yuan, Z., Zhang, Y., Xu, H., Guo, Y., Liang, C., Zhuang, X., 2011. Characterization of direct cellulase immobilization with superparamagnetic nanoparticles. Biocatalysis and Biotransformation 29 (2-3), 71-76.

Zhang, M., Su, R., Li, Q., Qi, W., He, Z., 2011. Enzymatic saccharification of pretreated corn stover in a fed-batch membrane bioreactor. Bioenergy Research 4 (2), 134-140. 